Prepared in cooperation with the U.S. Department of Energy, National Nuclear Security Administration Nevada Site Office, Office of Environmental Management under Interagency Agreement, DE-AI52-07NA28100

\title{
Digitally Available Interval-Specific Rock-Sample Data Compiled from Historical Records, Nevada National Security Site and Vicinity, Nye County, Nevada
}

\section{Coarse alluvium}

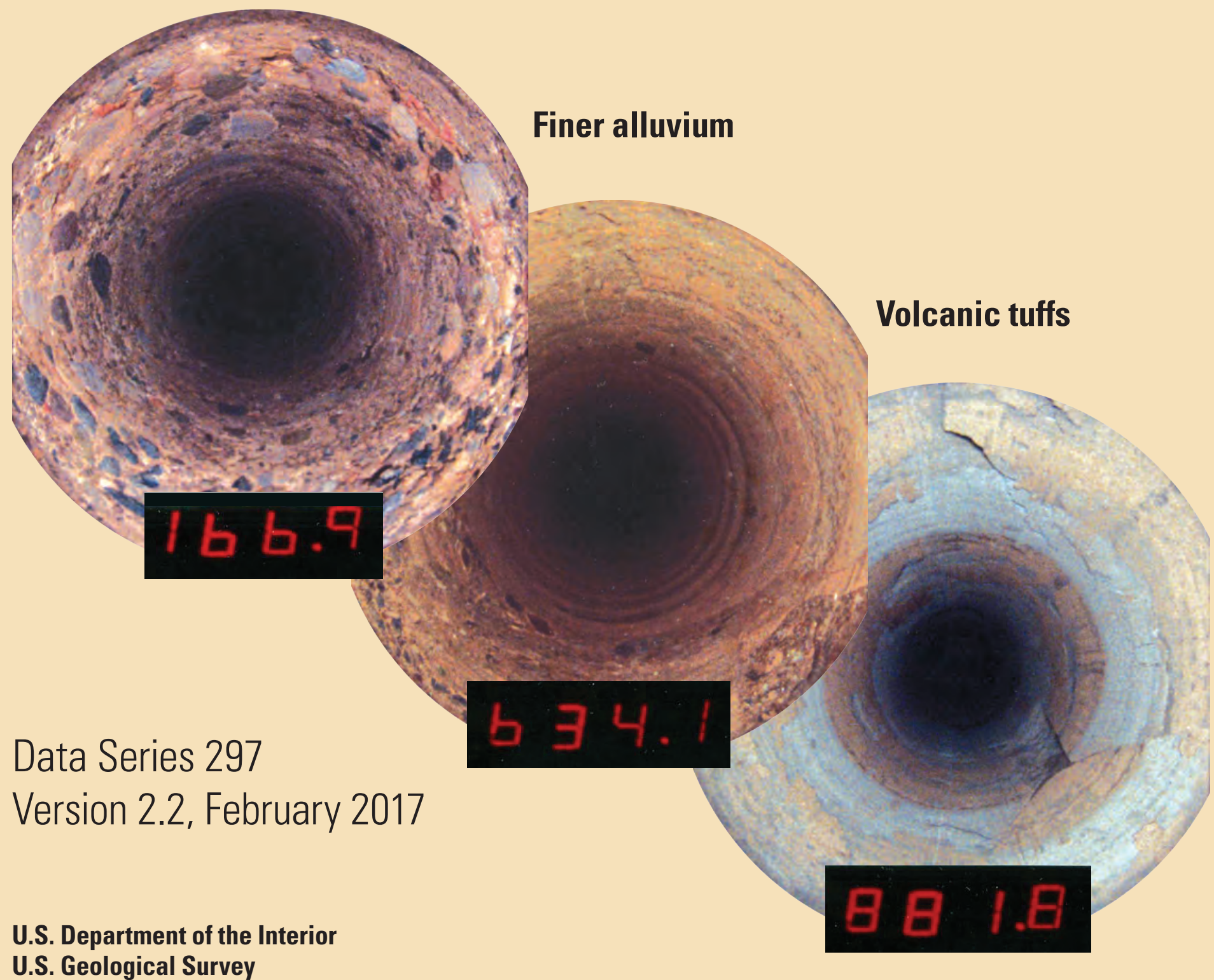




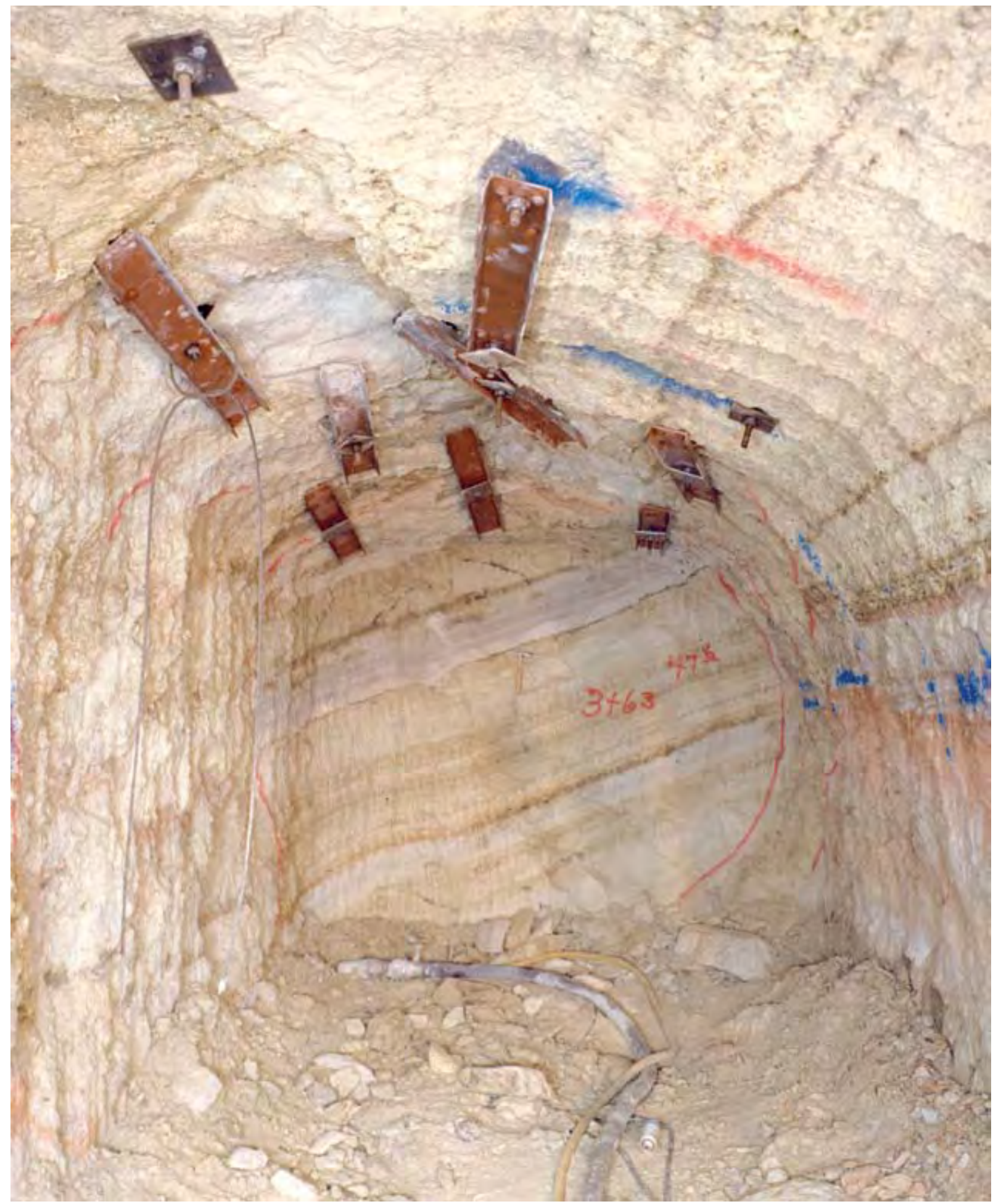

View inside reentry drift U -12n.10 A B shows volcanic tuffs from the Tertiary Tunnel Formation, $4 \mathrm{M}$ ember, beds 4C and 4D (Dean R. Townsend, Fenix and Scisson, Inc., written commun., October 5, 1976). The number 3+63 painted on the face indicates 363 feet from the portal opening. Photograph courtesy of Defense Threat Reduction Information A nalysis Center.

\section{Cover photograph}

Three downhole fish-eye camera views of emplacement hole U-2cs. View from 166.9 feet shows coarse alluvium. View from 634.1 feet shows coarse cobbly alluvium channels cut into finer alluvium. View from 881.8 feet shows a fault in the volcanic tuffs from the Tertiary Paintbrush Group. Photographs courtesy of Gayle A. Pawloski, L aw rence Livermore N ational Laboratory. 


\section{Digitally Available Interval-Specific Rock-Sample Data Compiled from Historical Records, Nevada National Security Site and Vicinity, Nye County, Nevada}

By David B. Wood

Prepared in cooperation with the U.S. Department of Energy, National

Nuclear Security Administration Nevada Site Office, Office of Environmental

Management under Interagency Agreement, DE-Al52-07NA28100

Data Series 297

Version 2.2, February 2017 


\title{
U.S. Department of the Interior DIRK KEMPTHORNE, Secretary
}

\author{
U.S. Geological Survey \\ Mark D. Myers, Director
}

\author{
U.S. Geological Survey, Reston, Virginia \\ First release: 2007 \\ Revised: 2009 (ver. 2.0) \\ Revised: August 2015 (ver. 2.1) \\ Revised: February 2017 (ver. 2.2)
}

\begin{abstract}
Any use of trade, firm, or product names is for descriptive purposes only and does not imply endorsement by the U.S. Government.

Although this information product, for the most part, is in the public domain, it also may contain copyrighted materials as noted in the text. Permission to reproduce copyrighted items must be secured from the copyright owner.
\end{abstract}

\author{
Suggested citation: \\ Wood, D.B., 2007, Digitally available interval-specific rock-sample data compiled from historical records, Nevada \\ National Security Site and vicinity, Nye County, Nevada (ver. 2.2, February 2017): U.S. Geological Survey Data Series \\ 297, 23 p., https://doi.org/10.3133/ds297. \\ ISSN 2327-638X (online)
}




\section{Contents}

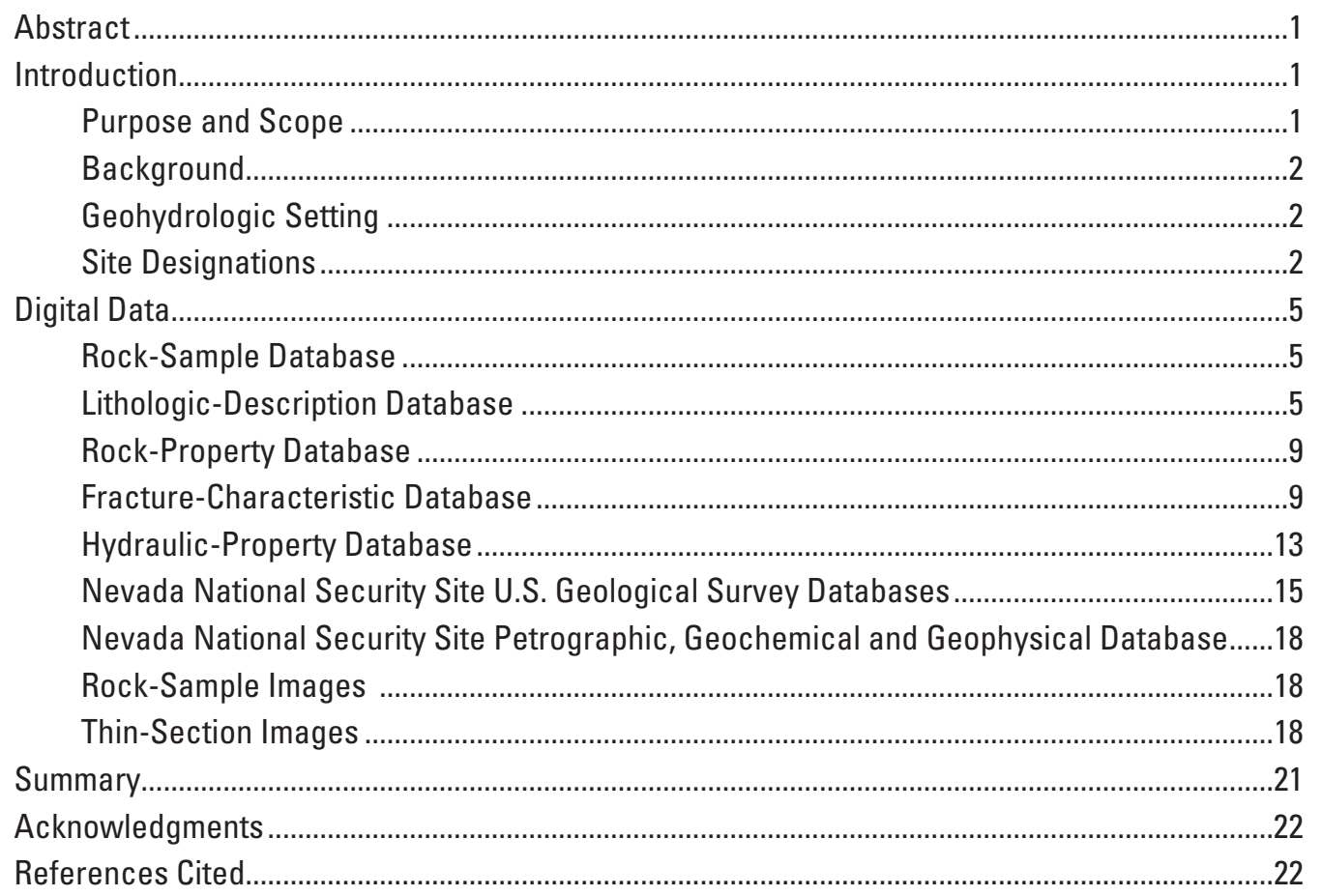




\section{Figures}

1. Map showing location of Nevada National Security Site and pertinent physiographic features, Nye County, Nevada

2. Map showing generalized distribution of rock types in vicinity of Nevada National Security Site, Nye County, Nevada

3. Map showing areal distribution of rock-sample sites in vicinity of Nevada National Security Site, Nye County, Nevada

4. Photographs showing examples of subsurface core and cuttings collected from exploratory holes at Nevada National Security Site, Nye County, Nevada $\ldots . . \ldots . \quad 7$

5. Map showing areal distribution of lithologic-description sites in vicinity of Nevada National Security Site, Nye County, Nevada

6. Profile showing example of generalized lithologic units in borehole ER-6-1, Nevada National Security Site, Nye County, Nevada

7. Map showing areal distribution of rock-property sites in vicinity of Nevada National Security Site, Nye County, Nevada

8. Profile showing examples of subsurface rock-property data collected at Nevada National Security Site, Nye County, Nevada .....

9. Map showing areal distribution of fracture-characteristic sites in vicinity of Nevada National Security Site, Nye County, Nevada

10. Photographs showing example of subsurface fracture characteristics in vertical core hole MH-2 in floor of emplacement drift U-12n.10 at 303.77 feet from portal opening, Nevada National Security Site, Nye County, Nevada

11. Map showing areal distribution of hydraulic-property sites in vicinity of Nevada National Security Site, Nye County, Nevada

12. Graph showing example of subsurface hydraulic-property data collected at Nevada National Security Site, Nye County, Nevada

13. Map showing areal distribution of site-characteristic sites in vicinity of Nevada National Security Site, Nye County, Nevada

14. Photograph showng view facing west of U-20bg monitoring hole on Pahute Mesa, Nye County, Nevada

15. Photograph showing view facing west toward Specter Range of SM-23-1 monitoring hole located in Mercury Valley, Nye Country, Nevada

16. Map showing areal distribution of petrographic, geochemical, and geophysical sites in vicinity of Nevada National Security Site, Nye County, Nevada ........... 19

17. Profile showing examples of subsurface geochemical data collected at Nevada National Security Site, Nye County, Nevada

18. Photograph showing $\mathrm{X}$-ray diffraction and fluorescence equipment $\ldots \ldots \ldots \ldots 21$ 


\section{Conversion Factors and Datums}

Inch/Pound to SI

\begin{tabular}{|c|c|c|}
\hline Multiply & By & To obtain \\
\hline \multicolumn{3}{|c|}{ Length } \\
\hline inch (in.) & 2.54 & centimeter (cm) \\
\hline inch (in.) & 25.4 & millimeter (mm) \\
\hline foot (ft) & 0.3048 & meter $(\mathrm{m})$ \\
\hline mile (mi) & 1.609 & kilometer (km) \\
\hline \multicolumn{3}{|c|}{ Area } \\
\hline square mile $\left(\mathrm{mi}^{2}\right)$ & 2.590 & square kilometer $\left(\mathrm{km}^{2}\right)$ \\
\hline \multicolumn{3}{|c|}{ Volume } \\
\hline barrel (bbl), (petroleum, 1 barrel=42 gal) & 0.1590 & cubic meter $\left(\mathrm{m}^{3}\right)$ \\
\hline gallon (gal) & 3.785 & liter $(\mathrm{L})$ \\
\hline gallon (gal) & 0.003785 & cubic meter $\left(\mathrm{m}^{3}\right)$ \\
\hline cubic foot $\mathrm{ft}^{3}$ ) & 0.02832 & cubic meter $\left(\mathrm{m}^{3}\right)$ \\
\hline \multicolumn{3}{|c|}{ Flow rate } \\
\hline foot per second (ft/s) & 0.3048 & meter per second (m/s) \\
\hline gallon per minute (gal/min) & 0.06309 & liter per second $(\mathrm{L} / \mathrm{s})$ \\
\hline gallon per day (gal/d) & 0.003785 & cubic meter per day $\left(\mathrm{m}^{3} / \mathrm{d}\right)$ \\
\hline \multicolumn{3}{|c|}{ Mass } \\
\hline ounce, avoirdupois (oz) & 28.35 & $\operatorname{gram}(\mathrm{g})$ \\
\hline pound, avoirdupois (lb) & 0.4536 & kilogram (kg) \\
\hline \multicolumn{3}{|c|}{ Pressure } \\
\hline bar & 100 & kilopascal (kPa) \\
\hline kilo bar (kb) & 1,000 & kilopascal (kPa) \\
\hline pound per square inch (lb/in²) & 6.895 & kilopascal (kPa) \\
\hline kilo pounds per square inch (kpsi) & 6.894757 & megapascal (MPa) \\
\hline \multicolumn{3}{|c|}{ Density } \\
\hline pound per cubic foot $\left(\mathrm{lb} / \mathrm{ft}^{3}\right)$ & 16.02 & kilogram per cubic meter $\left(\mathrm{kg} / \mathrm{m}^{3}\right)$ \\
\hline pound per cubic foot (lb/ft $\left.{ }^{3}\right)$ & 0.01602 & gram per cubic centimeter $\left(\mathrm{g} / \mathrm{cm}^{3}\right)$ \\
\hline pound per cubic foot $\left(\mathrm{lb} / \mathrm{ft}^{3}\right)$ & 0.01602 & megagram per cubic meter $\left(\mathrm{Mg} / \mathrm{m}^{3}\right)$ \\
\hline \multicolumn{3}{|c|}{ Specific capacity } \\
\hline $\begin{array}{l}\text { gallon per minute per foot } \\
[(\mathrm{gal} / \mathrm{min}) / \mathrm{ft})]\end{array}$ & 0.2070 & liter per second per meter [(L/s)/m] \\
\hline \multicolumn{3}{|c|}{ Electrical conductivity } \\
\hline micromhos per centimeter ( $\mu \mathrm{mho} / \mathrm{cm})$ & 1 & Microsiemens per centimeter $(\mu \mathrm{S} / \mathrm{cm})$ \\
\hline \multicolumn{3}{|c|}{ Velocity } \\
\hline foot per second (ft/s) & 0.0003048 & kilometer per second (km/s) \\
\hline
\end{tabular}

Temperature in degrees Celsius $\left({ }^{\circ} \mathrm{C}\right)$ may be converted to degrees Fahrenheit $\left({ }^{\circ} \mathrm{F}\right)$ as follows:

${ }^{\circ} \mathrm{F}=\left(1.8 x^{\circ} \mathrm{C}\right)+32$.

Temperature in degrees Fahrenheit $\left({ }^{\circ} \mathrm{F}\right)$ may be converted to degrees Celsius $\left({ }^{\circ} \mathrm{C}\right)$ as follows:

${ }^{\circ} \mathrm{C}=\left({ }^{\circ} \mathrm{F}-32\right) / 1.8$. 


\section{Conversion Factors and Datums}

Datums

Vertical coordinates are referenced to the North American Vertical Datum of 1929 (NGVD29); see altitude at portal opening, altitude of land surface, and reference point elevation in tables.

Horizontal coordinates are referenced to both the North American Datum of 1927 (NAD27) and 1983 (NAD83); see Nevada State Plane coordinates, latitude/longitude, decimal latitude/ longitude, and UTM coordinates in tables.

Altitude, as used in this report, refers to distance above the vertical datum. 


\title{
Digitally Available Interval-Specific Rock-Sample Data Compiled from Historical Records, Nevada National Security Site and Vicinity, Nye County, Nevada
}

\author{
By David B. Wood
}

\section{Abstract}

Between 1951 and 1992, 828 underground tests were conducted on the Nevada National Security Site, Nye County, Nevada. Prior to and following these nuclear tests, holes were drilled and mined to collect rock samples. These samples are organized and stored by depth of borehole or drift at the U.S. Geological Survey Core Library and Data Center at Mercury, Nevada, on the Nevada National Security Site. From these rock samples, rock properties were analyzed and interpreted and compiled into project files and in published reports that are maintained at the Core Library and at the U.S. Geological Survey office in Henderson, Nevada. These rock-sample data include lithologic descriptions, physical and mechanical properties, and fracture characteristics. Hydraulic properties also were compiled from holes completed in the water table. Rock samples are irreplaceable because pre-test, in-place conditions cannot be recreated and samples can not be recollected from the many holes destroyed by testing. Documenting these data in a published report will ensure availability for future investigators.

\section{Introduction}

Rock-sample data are available from both underground (boreholes, shafts, tunnels, and drifts) and surface (mostly outcrops and a few trenches) sites located on and around the Nevada National Security Site (NNSS, formerly Nevada Test Site [NTS]), Nye County, Nevada. These data include rocksample interval locations, lithologic descriptions, physical and mechanical rock properties, fracture characteristics, and hydraulic properties. Acronyms and abbreviations in common usage at the NNSS are described in the auxiliary 'nnss_acr_ abv' worksheets in the databases (https://www.sciencebase. gov/mercury/index.html\#/).

\section{Purpose and Scope}

This report documents rock samples and data derived from these samples in digital spreadsheets. Specifically, this report presents five databases (rock samples, lithologic descriptions, rock properties, fracture characteristics, and hydraulic properties). Data presented in these databases were obtained from rock samples and compiled from paper records contained in the historical files and from published reports located at the U.S. Geological Survey (USGS) Core Library and Data Center at Mercury (on the NNSS) and at the USGS office in Henderson, Nevada.

The many logs and samples presented in this report represent a large investment over many years and are unique, in that in many cases, they cannot be acquired again. Pretest, in-place conditions, as well as conditions that existed prior and during nuclear testing can not be recreated and rock samples (and associated analysis and interpretations) from the many holes destroyed by testing can not be recollected. Measurement techniques continuously evolve over time and the methods of interpretation are constantly being revised as new techniques become available. The application of these new methods often depends on the availability of the original subsurface data and the ability of individuals to understand both how these data were collected and how associated interpretations were developed. Documenting these data in a published report will ensure data availability for posterity. Furthermore, the condition of the original paper records is already poor and data are illegible for some records. The continuing deterioration of these records could preclude their availability to future investigators. All subsurface data, regardless of program or application, needs to be archived for future use at the NNSS. Only through publication and archiving, can these data be fully developed and utilized in making sound decisions concerning future activities at the NNSS and protection of human health and safety. 


\section{Background}

The NNSS (fig. 1) was established by the United States during the 1950s as the primary continental proving ground for nuclear testing and peaceful applications of nuclear explosions (U.S. Congress, 1989). The site, which occupies about 1,375 $\mathrm{mi}^{2}$ of south-central Nevada, was chosen by the Atomic Energy Commission (AEC, predecessor to the U.S. Department of Energy [DOE]) primarily because of its remoteness from population centers and because the land was under military control (Fehner and Gosling, 2000). Since 1951, 928 tests have been conducted at the NNSS. Of these tests, 828 were detonated underground (U.S. Department of Energy, 2000). In addition to the holes used for underground emplacement of nuclear weapons, many auxiliary holes were drilled and mined adjacent to the emplacement holes for collecting supplemental data. The databases presented in this report represent an accumulation of data from each of these holes.

Geologists, geophysicists, hydrologists, and other specialists have worked in cooperation with the DOE, National Nuclear Security Administration, Nevada Site Office (and its predecessors) and the National Laboratories to provide Earth science data since 1956 (P.P. Orkild, U.S. Geological Survey, written commun., 1987). The USGS and AEC agreed to cooperate in geologic, geophysical, and hydrologic investigations at the NNSS under a memorandum of understanding (No. AT (2902)474) dated June 1, 1957. A modification to the memorandum which incorporates the entire agreement (Modification No. 3, Schedule 1 to Appendix A, page 3, item 4), dated April 3, 1959 states:

\section{"Operation of a Field and Geological Data Repository and Core Library. Maintain field records at a central location at NTS which will have a recurring use for reference purposes. It is intended that the Geological Survey have on file representative logs of significant excavations, and establish and maintain core libraries (exclusive of radiochemical cores) in accordance with mutually agreed USGS-Commission rules and procedures."}

The USGS Core Library and Data Center was established in temporary quarters during 1959 at Mercury, Nevada, and a permanent facility was built during the late 1960s (G.L. Dixon, U.S. Geological Survey, written commun., 1983). Because the USGS was designated as the caretaker of the rock samples, personnel from the National Laboratories as well as DOE and Department of Defense (DOD) contractors were continually accessing rock samples at the Core Library. This resulted in the USGS amassing paper copies of many of the preliminary results of the rock-sample analyses and interpretations as well as internal and published reports resulting from this work.

\section{Geohydrologic Setting}

The NNSS is entirely within the Great Basin region of the Basin and Range physiographic province. The region is characterized by mountain ranges with a general northsouth orientation separated by basins (valleys) that are filled by accumulations of unconsolidated to partly consolidated sedimentary deposits and underlain by consolidated rocks that also form the surrounding ranges (Stewart, 1980). The unconsolidated rocks at the NNSS consist of basin fill and volcanic and sedimentary rocks. Consolidated rocks consist of volcanic, metamorphic and intrusive, siliciclastic, and carbonate rocks. The generalized distribution of rock types in the vicinity of the NNSS is shown in figure 2.

The stratigraphic nomenclature at the NNSS has evolved over time. The USGS conducted surface-mapping field work between 1958 and 1964 that resulted in the publication of thirty-four 7.5-minute geologic maps (Byers and others, 1989). The stratigraphy and lithology has been continually refined by investigators from various organizations (including DOE/ DOD subcontractors, the National Laboratories, and USGS) by inspection of rock samples collected from holes drilled and mined at the NNSS and vicinity. This has resulted in many informal units in common usage at the NNSS. Volcanic rocks are summarized in Byers and others (1976) and Sawyer and others (1994). Carbonate rocks are summarized in Cole and Cashman (1999). Stratigraphic units are lumped into hydrogeologic units and discussed in IT Corporation (1996a, 1996b), Faunt and others (2004), and Sweetkind and others (2004).

The hydrologic setting of the NNSS is similar to that of most of the Basin and Range province. It is characterized by localized aquifers within the alluvial deposits in the eastern, central, and southern parts. Regional aquifers are mostly within complexly folded and faulted limestones and dolomites that underlie the localized aquifers in the eastern and southern parts, but also are within fractured volcanic rocks in the western part of the NNSS. Much of the ground-water flow is interbasin; that is, flow is not strictly controlled by the surface topography that defines surface-water drainage basins (Blankennagel and Weir, 1973; Winograd and Thordarson, 1975; Laczniak and others, 1996; Slate and others, 2000; Potter and others, 2002; Workman and others, 2002).

\section{Site Designations}

Rock-sample sites are identified primarily by the USGS NNSS unique number and secondarily by the NNSS area (the NNSS is comprised of 26 administrative areas [fig. 1]), a Redbook hole number, and USGS National Water Information System (NWIS) site identification number (U.S. Geological Survey, 2005). A unique number is necessary because spatial $(X-Y)$ coordinates are currently not available for some sites. Site designations are described in the tables at https://www. sciencebase.gov/mercury/index.html\#/. 


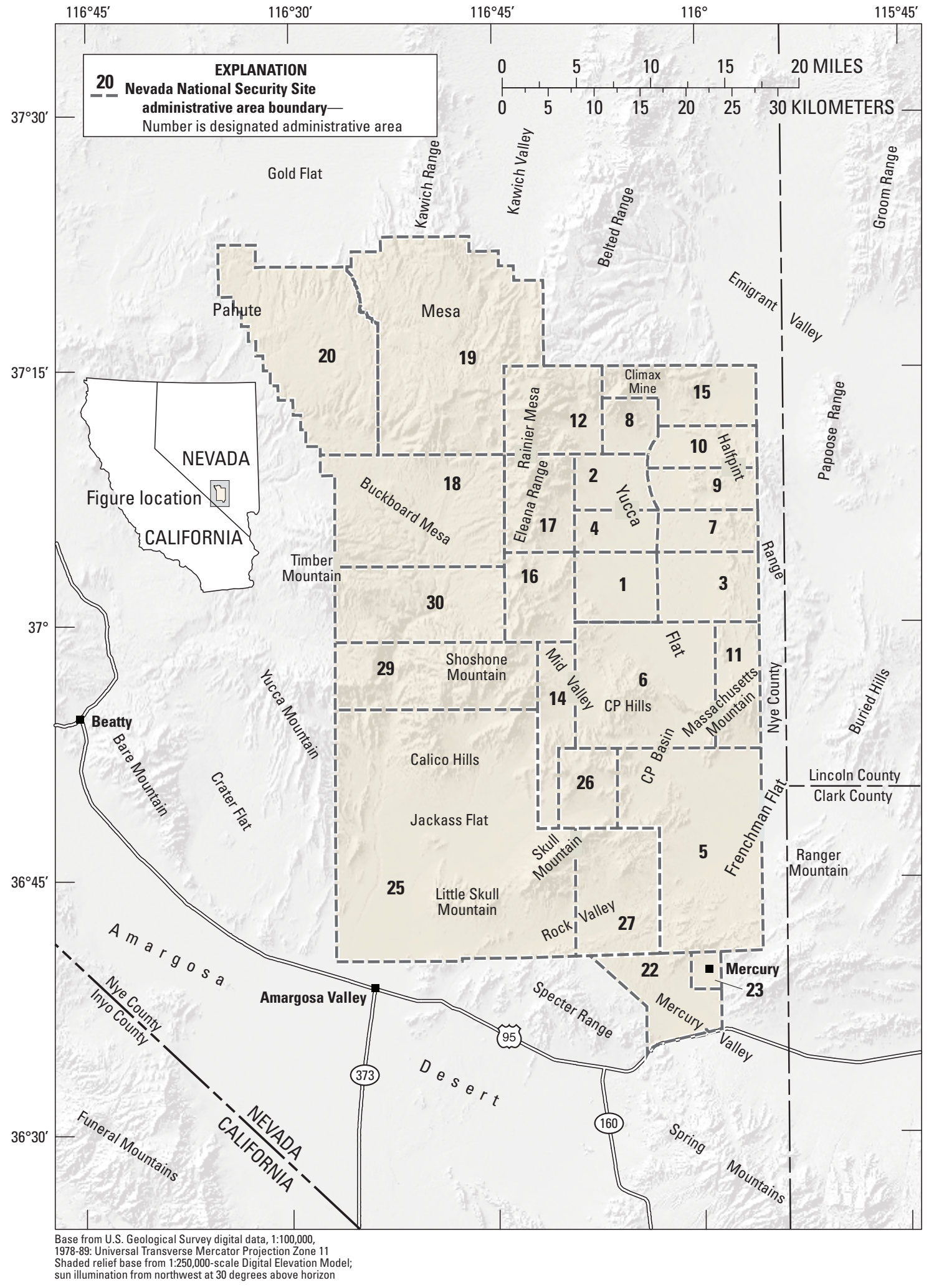

Figure 1. Location of Nevada National Security Site and pertinent physiographic features, Nye County, Nevada. 


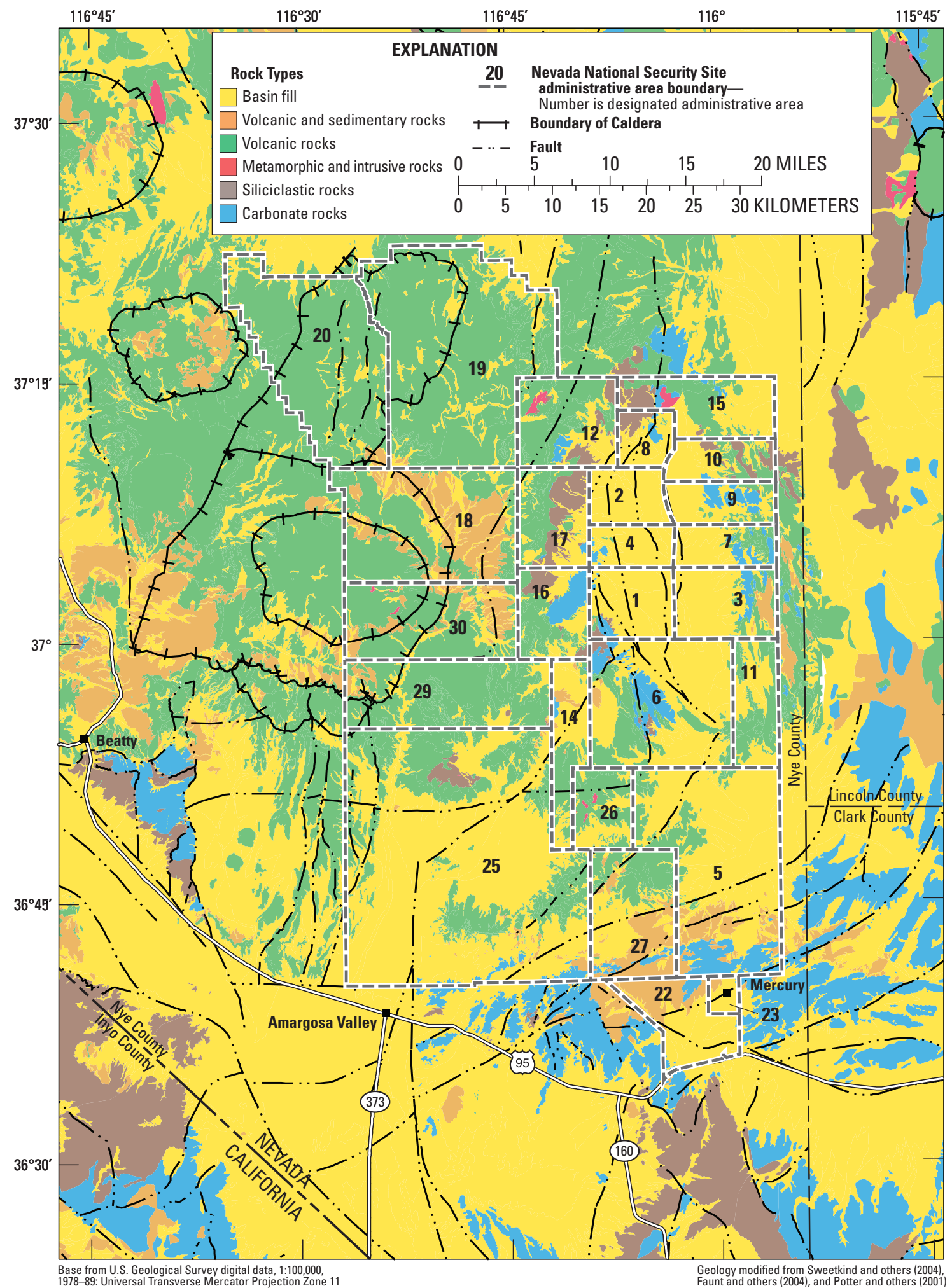

Figure 2. Generalized distribution of rock types in vicinity of Nevada National Security Site, Nye County, Nevada. 


\section{Digital Data}

The USGS compiled both Microsoft ${ }^{\circledR}$ Excel spreadsheets and Microsoft ${ }^{\oplus}$ Access tables, by depth interval, of available rock-sample, thin-section (prepared from rock samples), and aquifer-test data stored at the USGS Core Library and Data Center in Mercury and the USGS office in Henderson, Nevada. These digital spreadsheets and tables are the RockSample database, Lithologic-Description database, RockProperty database, Fracture-Characteristic database, and Hydraulic-Property database. Records were compiled for vertical (boreholes and shafts) and horizontal (tunnels and drifts) underground sites and for surface locations (mostly outcrops and a few trenches). Rock-sample locations were inventoried by personnel stationed at the Mercury facility. Rock-sample records were compiled by personnel stationed at the Henderson office from paper copies of records contained in the historical files stored at the Mercury and Henderson locations and from paper copies of published reports. Thinsection compilations were provided in electronic format. A small percentage of lithologic descriptions, rock properties, and fracture characteristics were provided in electronic format towards the end of the study.

\section{Rock-Sample Database}

The USGS catalogued interval-specific locations for rock samples and thin sections (prepared from rock samples)collected from both underground and surface sites located on and around the NNSS (ig. 3 ). The Rock-Sample database presents locations of rock samples and thin sections collected by DOE/DOD contracting organizations, the National Laboratories, and USGS and stored at the USGS Core Library. The database is both a digital spreadsheet and table (https://www.sciencebase.gov/mercury/index.html\#l core). Locations of all rock samples and thin sections stored at the Mercury facility have been compiled. However, rock samples stored at the USGS Yucca Mountain Program (YMP) sample management facility in NNSS Area 25 (fig. 1) are part of another program and have not been included in this compilation.
A core sample collected from exploratory hole UE-20f and a cuttings sample collected from exploratory hole UE-14b are used to show examples of rock-sample data at the NNSS. Hole UE-20f is the deepest hole drilled at the NNSS and the core sample collected from the bottom (13,670-13,686 foot) interval of this hole shows an example of welded volcanic tuff. Wooden blocks indicate sections of core removed from the USGS Core Library (fig. 4A). The cuttings sample collected from the 1,120- to 2,160-ft interval of exploratory hole UE-14b shows an example of variations in welded volcanic tuffs (ig. 4B).

\section{Lithologic-Description Database}

The USGS compiled interval-specific records of lithologic descriptions for both underground and surface sites located on and around the NNSS (fig. 5). The LithologicDescription database presents lithologies interpreted and re-interpreted from rock samples and geophysical and video logs in boreholes and shafts and mapped inside tunnels and drifts by investigators from DOE/DOD contracting organizations, the National Laboratories, and USGS. The database is both a digital spreadsheet and table (https:// www.sciencebase.gov/mercury/index.html\#/lith). Lithologic descriptions have been compiled for sites located in Frenchman, Jackass and Yucca Flats, and on Buckboard, Pahute, and Rainier Mesas, and parts of the Amargosa Desert near the NNSS (fig. 1).

The lithologic-description data for borehole ER-6-1 are used to show a graphical example of generalized lithologic units at the NNSS (fig. 6). The general units penetrated in this hole are alluvium, nonwelded to welded and bedded tuff, dolomite, and quartzite. The lithology was interpreted by Sigmund L. Drellack, Jr. and Lance B. Prothro from National Security Technologies, LLC and by Robert L. McCall from Stoller-Navarro Joint Venture. 


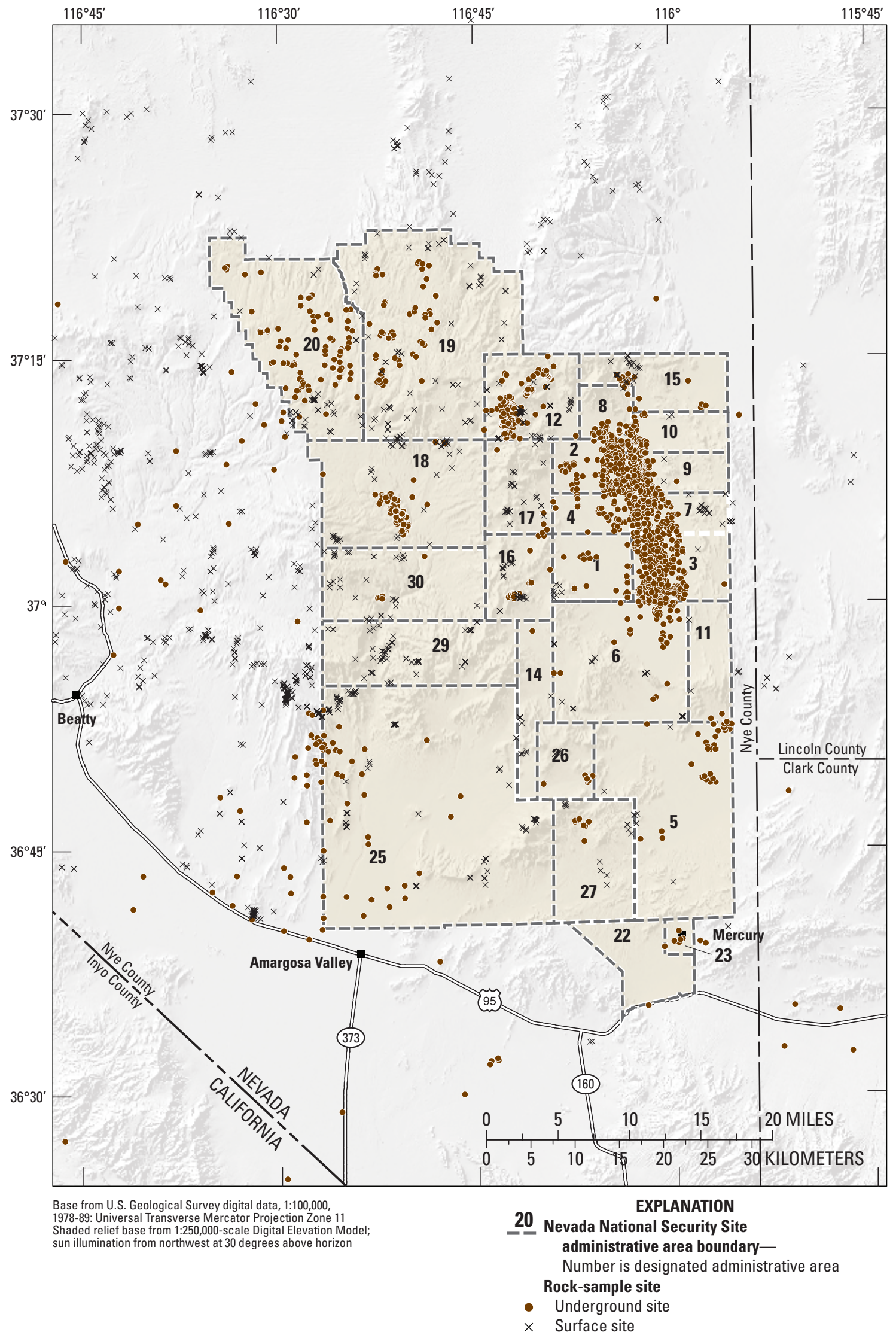

Figure 3. Areal distribution of rock-sample sites in vicinity of Nevada National Security Site, Nye County, Nevada. 


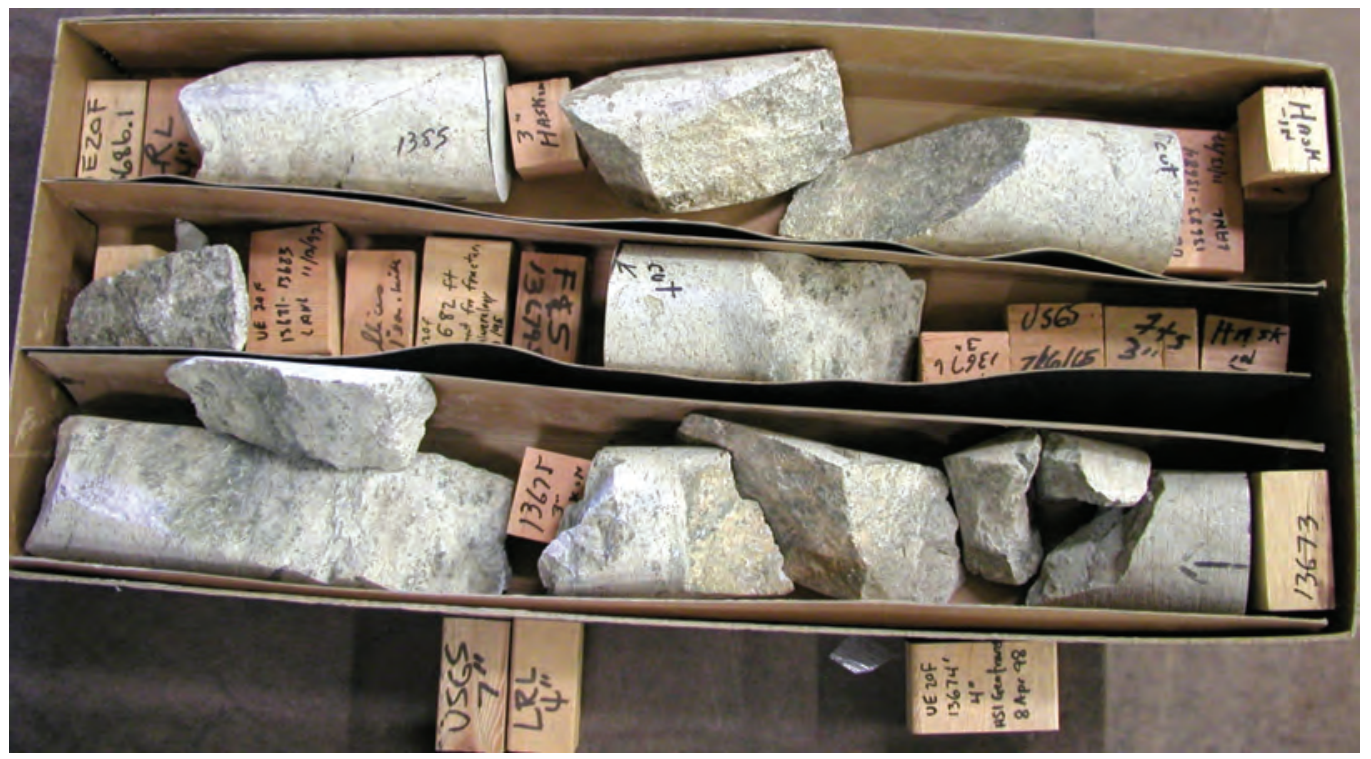

A. Subsurface core collected from bottom interval of exploratory hole UE-20f; deepest hole drilled at Nevada National Security Site. Core sample shows welded volcanic tuff from 13,670- to 13,686-foot interval. Wooden blocks indicate sections of core removed from U.S. Geological Survey Core Library. Photograph taken by Jerry Magner, U.S. Geological Survey.

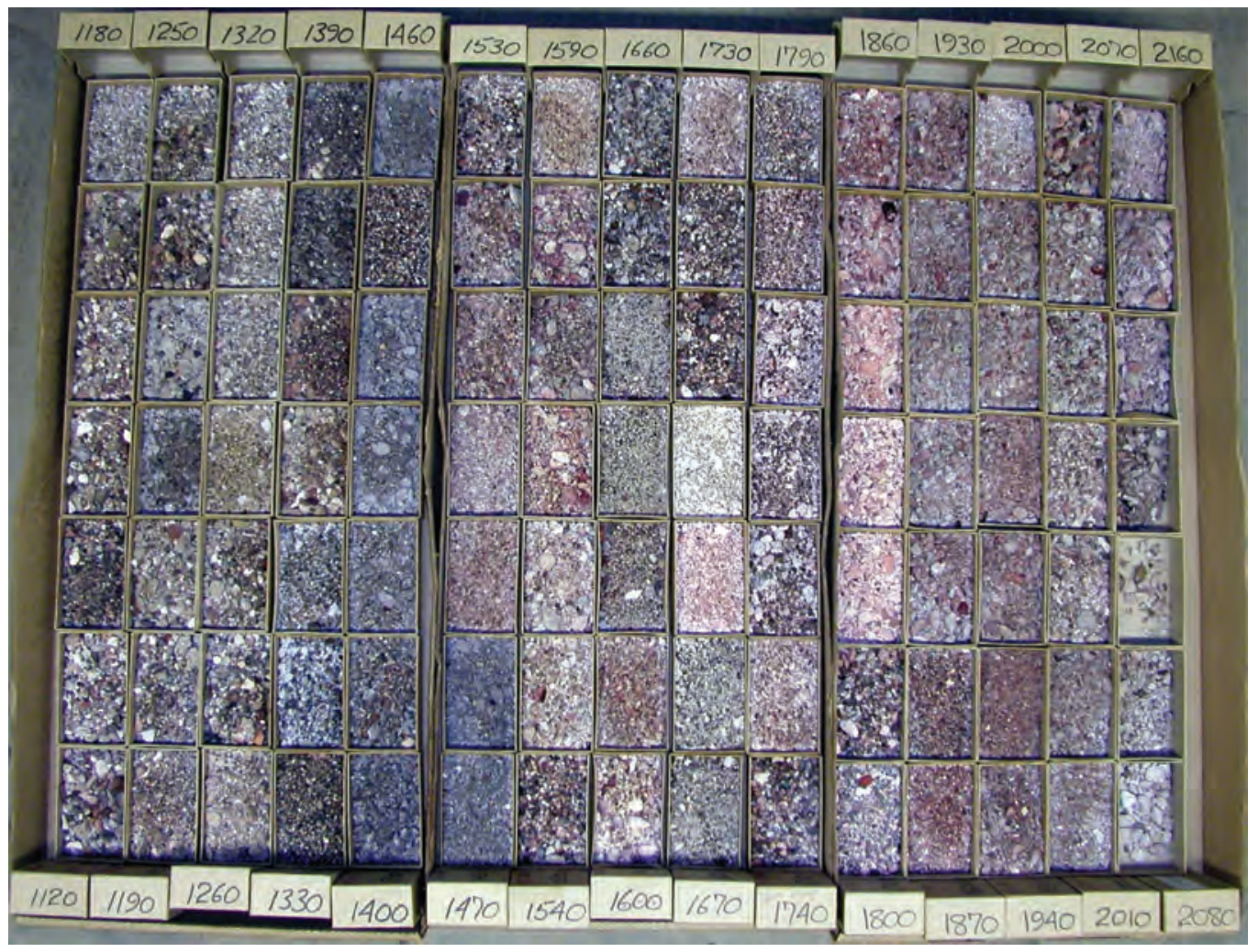

B. Subsurface cuttings collected from exploratory hole UE-14b. Cuttings sample shows variations in welded volcanic tuffs from 1,120- to 2,160-foot interval. Photograph taken by Jerry Magner, U.S. Geological Survey.

Figure 4. Examples of subsurface core and cuttings collected from exploratory holes at Nevada National Security Site, Nye County, Nevada. 


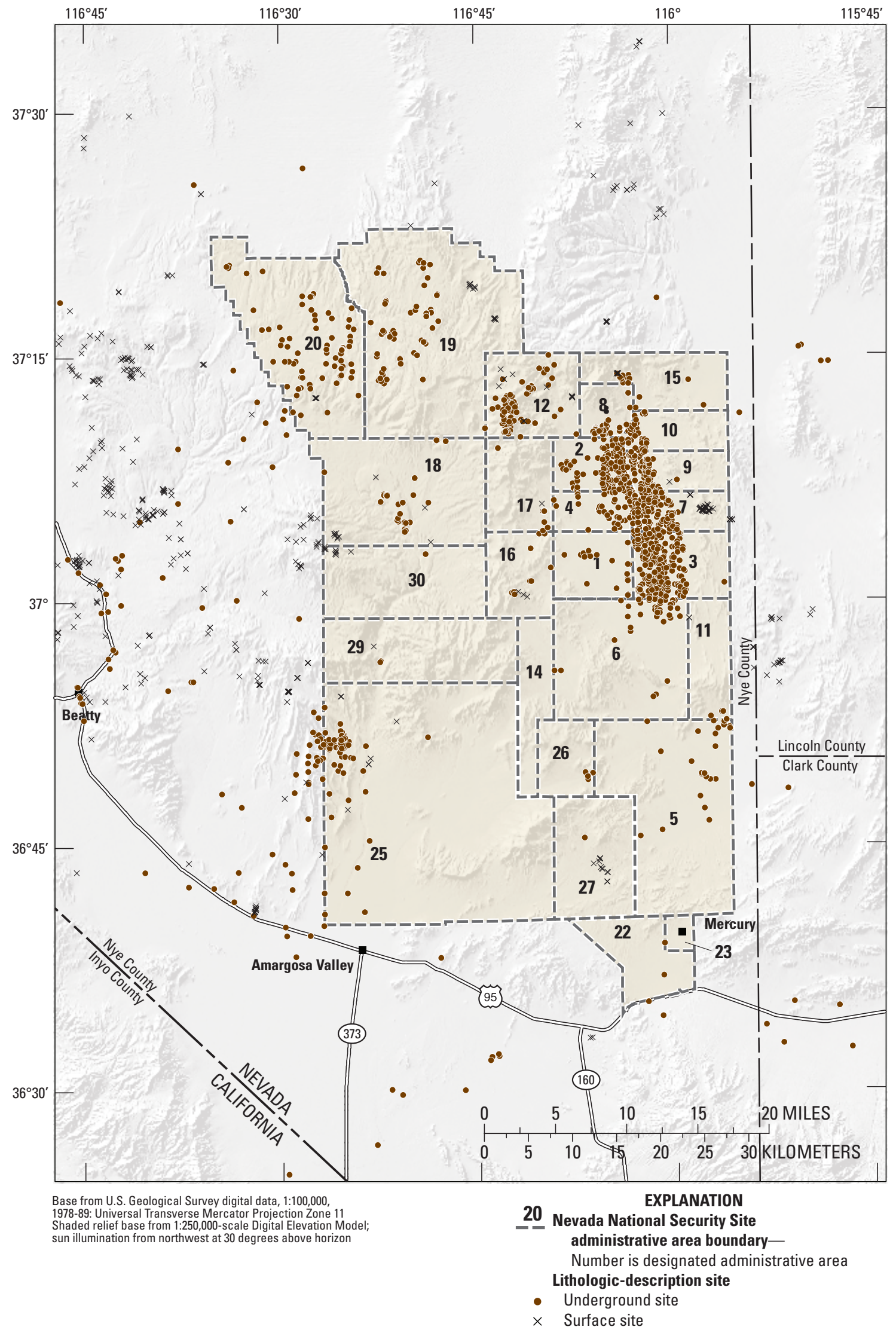

Figure 5. Areal distribution of lithologic-description sites in vicinity of Nevada National Security Site, Nye County, Nevada. 


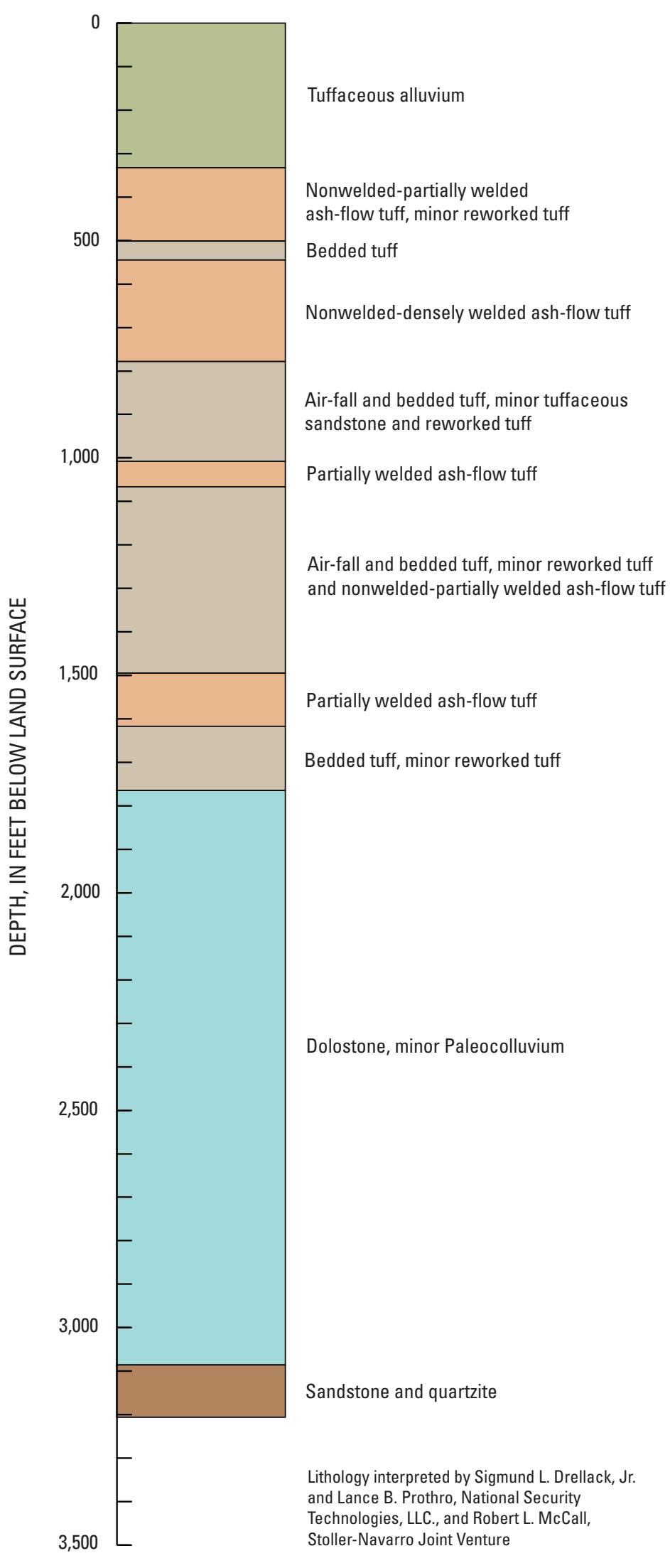

\section{Rock-Property Database}

The USGS compiled interval-specific records of rock-property data for both underground and surface sites located on and around the NNSS (fig. 7). The Rock-Property database presents physical and mechanical properties analyzed from rock samples by investigators from DOE/DOD contracting organizations, the National Laboratories, and USGS. The database is both a digital spreadsheet and table (https://www. sciencebase.gov/mercury/index.html\#/rock). Physical and mechanical rock properties have been compiled for sites located in Frenchman and Yucca Flats and on Buckboard, Pahute, and Rainier Mesas (fig. 1). Physical and mechanical rock properties are available but have not been compiled for holes located in Jackass Flat (fig. 1).

Samples collected from exploratory hole U-4d Ex. \#1 and analyses contained in Lawrence Livermore National Laboratory project files are used to show examples of rock-property data at the NNSS. Depth profiles are shown for grain density, wet (natural-state) bulk density, and wet water content by weight from exploratory hole U-4d Ex. \#1 (fig. 8).

\section{Fracture-Characteristic Database}

The USGS compiled interval-specific records of fracture-characteristic data for both underground and surface sites located on and around the NNSS (fig. 9). The Fracture-Characteristic database presents locations of fractures interpreted from rock samples and geophysical and video logs in boreholes and shafts and mapped inside tunnels and drifts by investigators from DOE/DOD contracting organizations, the National Laboratories, and USGS. The database is both a digital spreadsheet and table (https://www.sciencebase.gov/ mercury/index.html\#/fracture). Fracture characteristics have been compiled for sites located in Frenchman and Yucca Flats, and on Buckboard, Pahute, and Rainier Mesas (fig 1). Fracture characteristics are available but have not been compiled for holes located in Jackass Flat (fig. 1).

A core sample collected from the core hole MH-2, drilled vertically in the invert (floor) of emplacement drift U-12n.10 at $303.77 \mathrm{ft}$ from the portal opening, is used to show an example of fracture-characteristic data at the NNSS. Slickensides and black staining on fracture

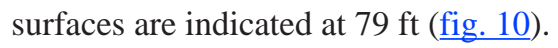

Figure 6. Example of generalized lithologic units in borehole ER-6-1, Nevada National Security Site, Nye County, Nevada. 


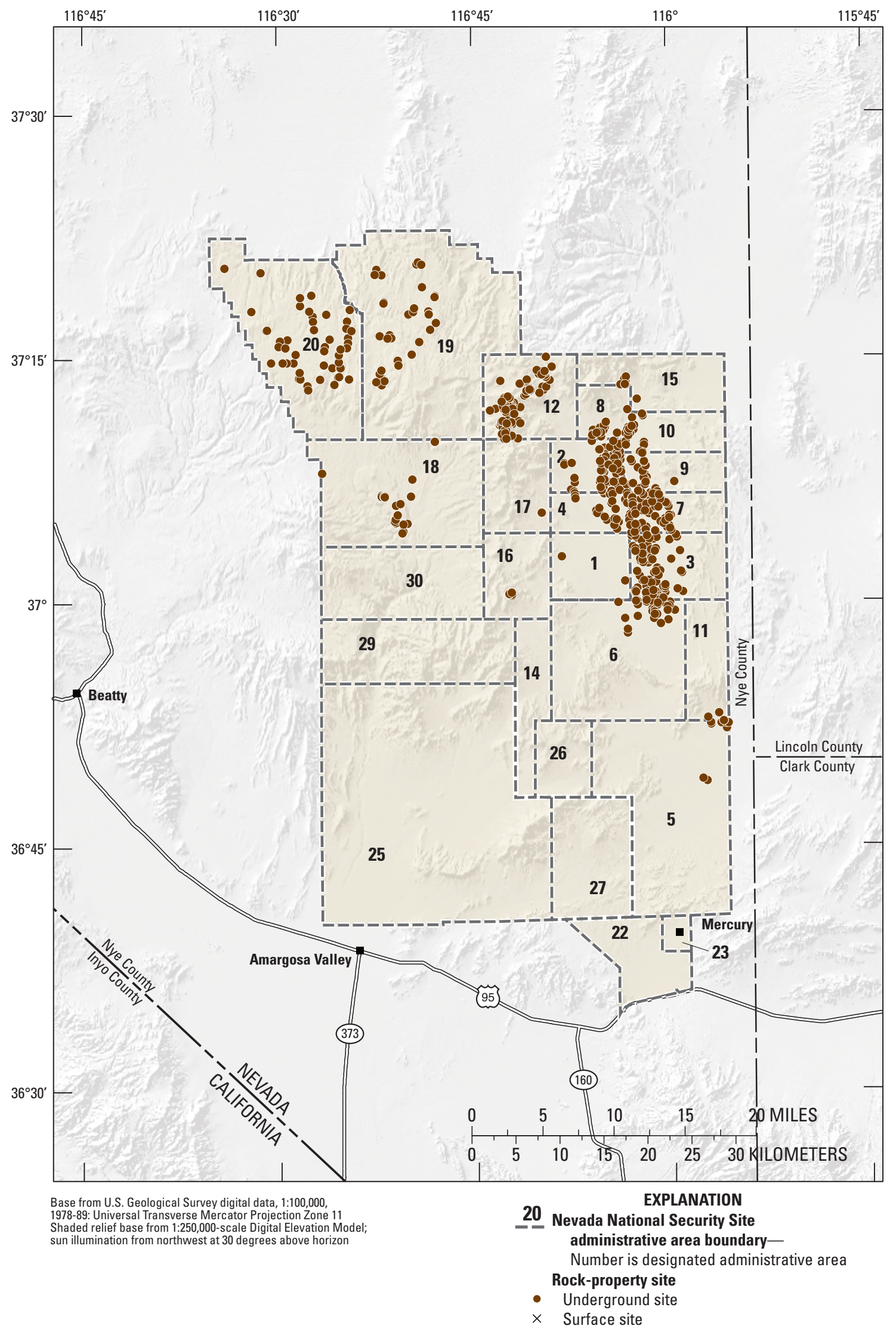

Figure 7. Areal distribution of rock-property sites in vicinity of Nevada National Security Site, Nye County, Nevada. 

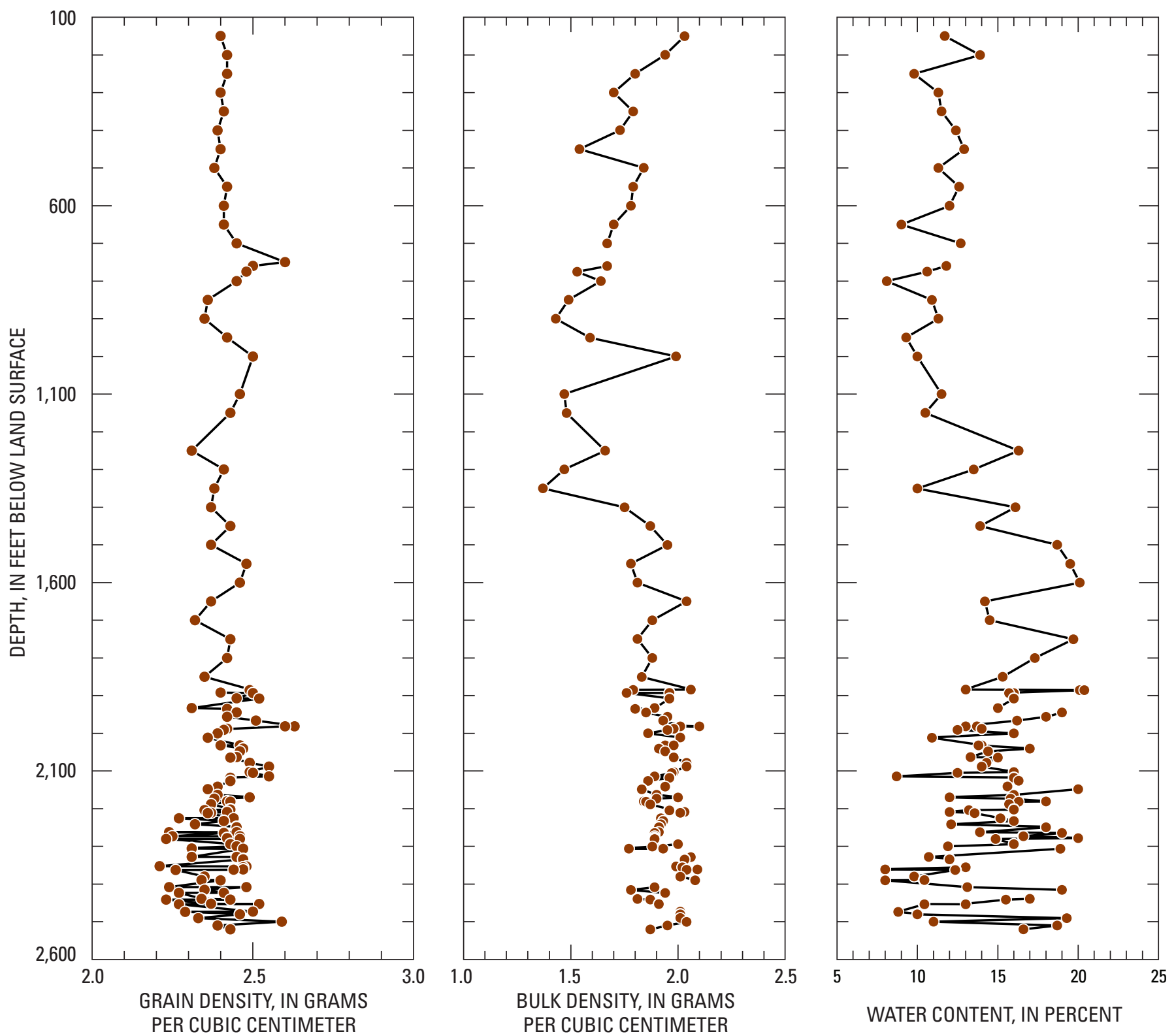

Figure 8. Examples of subsurface rock-property data collected at Nevada National Security Site, Nye County, Nevada. Depth profiles of grain density, wet (natural-state) bulk density, and wet water content by weight are from exploratory hole U-4d Ex.\#1. Anomalous values not shown. 


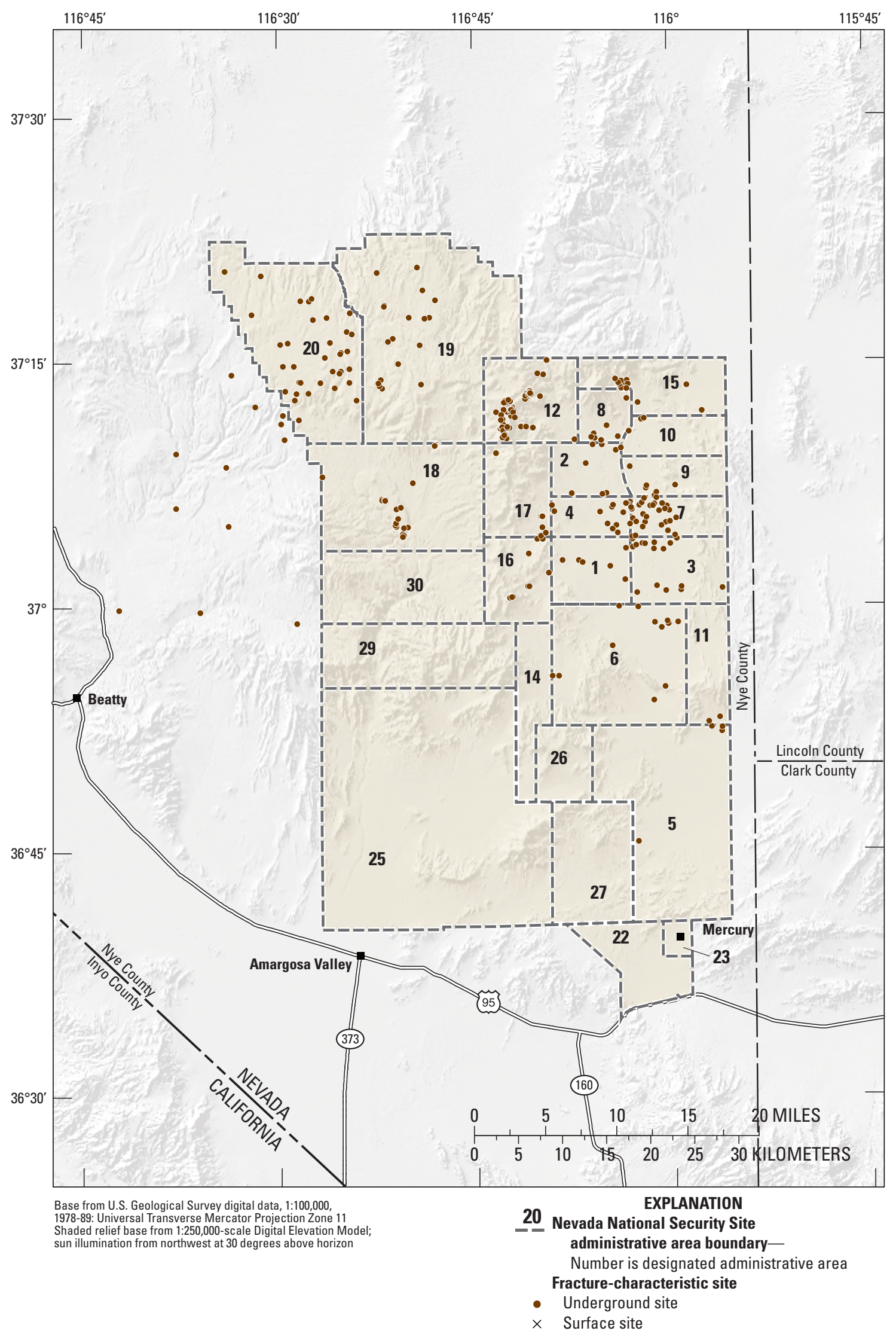

Figure 9. Areal distribution of fracture-characteristic sites in vicinity of Nevada National Security Site, Nye County, Nevada. 


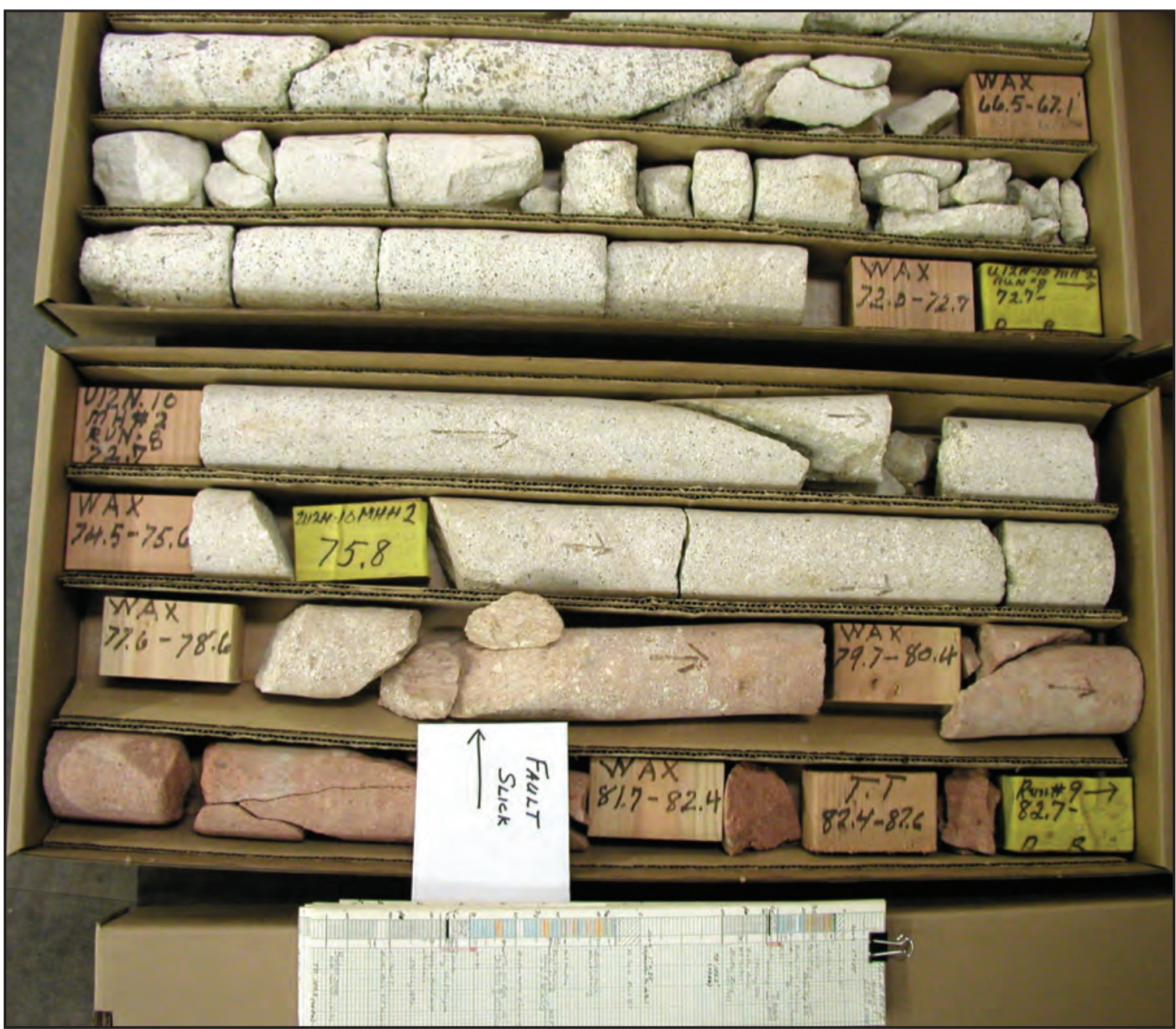

Figure 10. Example of subsurface fracture characteristics in vertical core hole $\mathrm{MH}-2$ in floor of emplacement drift U-12n.10 at 303.77 feet from portal opening, Nevada National Security Site, Nye County, Nevada. Core sample shows slickensides and black staining on fracture surfaces at 79 feet. Photograph taken by Jerry Magner, U.S. Geological Survey.

\section{Hydraulic-Property Database}

The USGS compiled interval-specific records of hydraulic-property data for both underground and surface sites located on and around the NNSS (ig. 11). The HydraulicProperty database presents water-level response from injection and withdrawal of water during aquifer tests conducted by investigators from DOE/DOD contracting organizations, the National Laboratories, and USGS. The database is both a digital spreadsheet and table (https://www.sciencebase.gov/ mercury/index.html\#/hydro). Hydraulic properties have been compiled for sites located in Frenchman and Yucca Flats, and on Buckboard, Pahute, and Rainier Mesas (fig. 1). Hydraulic properties are available but have not been compiled for holes located in Jackass Flat (fig. 1).

Aquifer testing conducted in water well WW-A and reported in Price and Thordarson (1961) are used to show examples of hydraulic-property data at the NNSS. Water-level recovery is shown following bailing tests of 3,000, 74, and 33 gallons, respectively (fig. 12). 


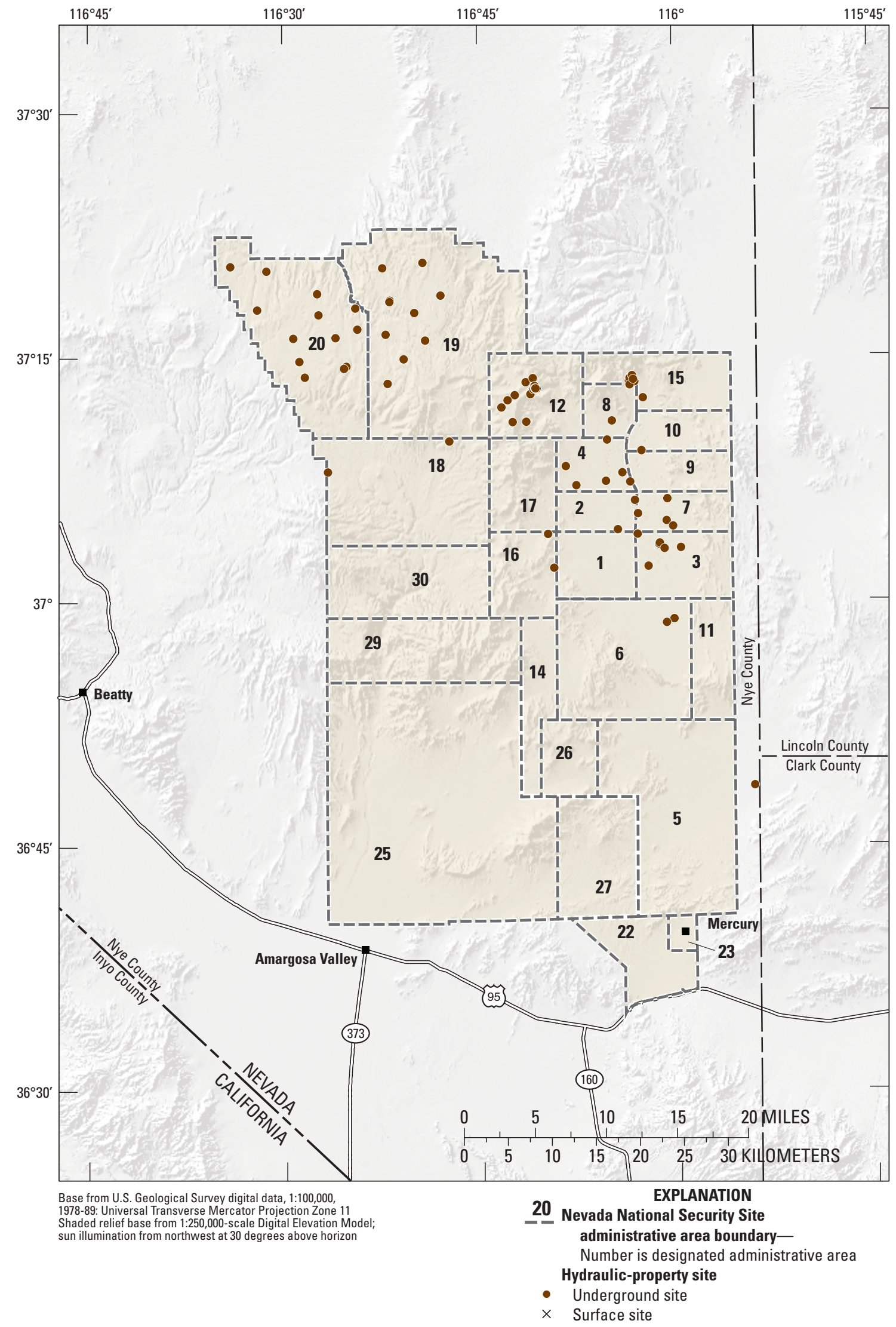

Figure 11. Areal distribution of hydraulic-property sites in vicinity of Nevada National Security Site, Nye County, Nevada. 


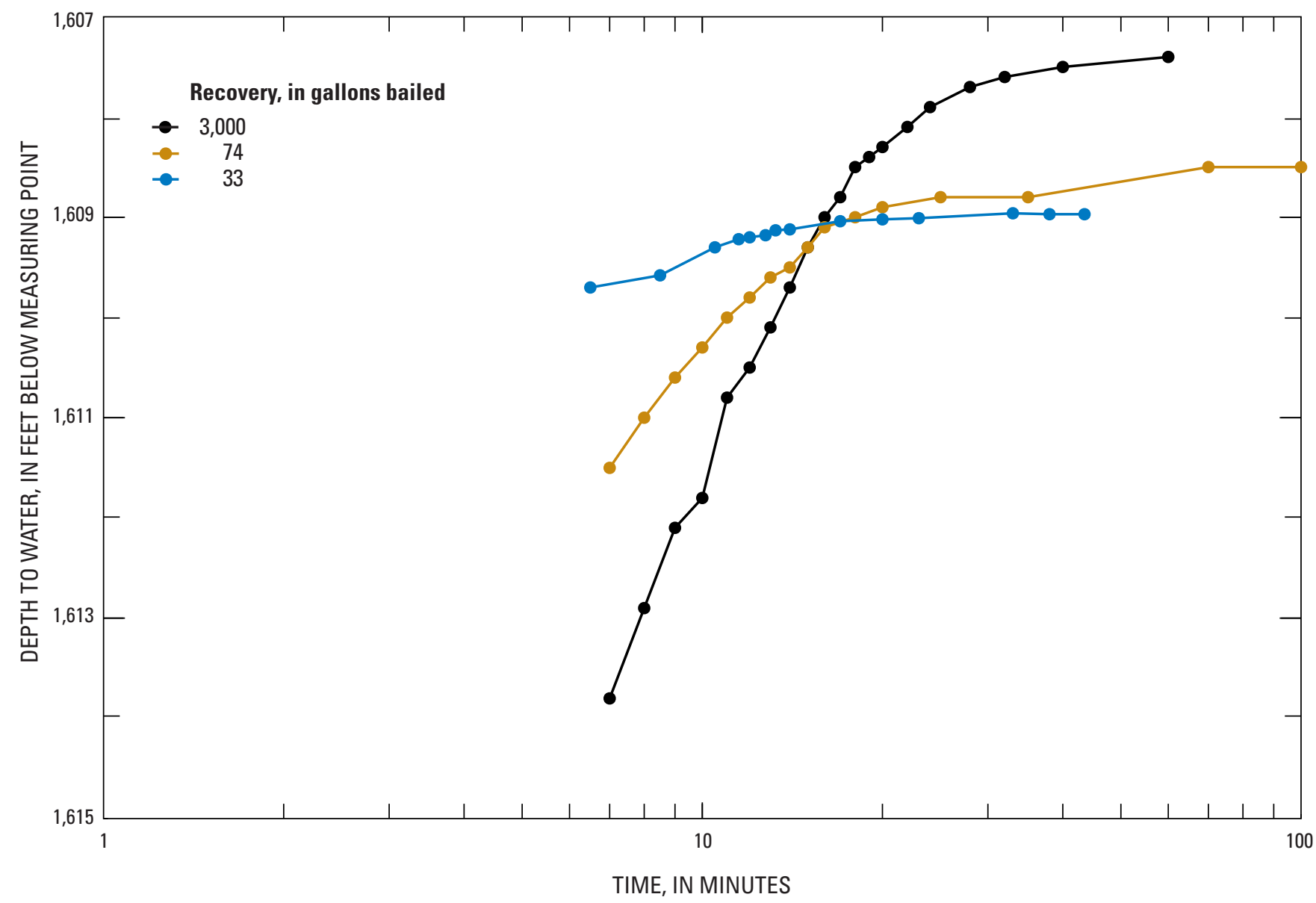

Figure 12. Example of subsurface hydraulic-property data collected at Nevada National Security Site, Nye County, Nevada. Recovery shown from three bailing tests conducted in water well WW-A.

\section{Nevada National Security Site U.S. Geological Survey Databases}

The combined NNSS USGS Databases Miscrosoft ${ }^{\circledR}$ Access $^{\circledR}$ tables (https://www.sciencebase.gov/mercury/\#/ database) contain the Miscrosoft ${ }^{\circledast}$ Excel $^{\circledast}$ versions of the Lithologic-Description, Rock-Property, Rock-Sample, Fracture-Characteristic, and Hydraulic-Property Databases. Most redundant data have been moved into a separate SiteCharacteristic Database table (fig. 13). These data tables were developed in Excel ${ }^{\circledR}$ as stand-alone databases and are offered in Access ${ }^{\circledR}$ for quicker response time. The USGS NNSS unique number field links the tables and the redundant USGS NNSS sort order field is retained in each table to maintain intended sort order. The redundant Map and/or stratigraphic unit symbol, LANL PGG Database loc_id, LANL PGG Database sam_id, and LANL PGG Database spl_id fields are retained in the rock-sample, lithologic-description, and fracturecharacteristic tables for both informational and linking purposes. The USGS NNSS unique number field also is listed prior to the USGS NNSS sort order field in the hydraulicproperty table for sorting purposes. Field contents are the same as described for the Excel ${ }^{\circledR}$ databases. However, the Site-Characteristic Database table includes additional fields (https://www.sciencebase.gov/mercury/index.html\#/database). Two examples of monitoring holes used in this report are shown in figure 14 and $\underline{15}$. 


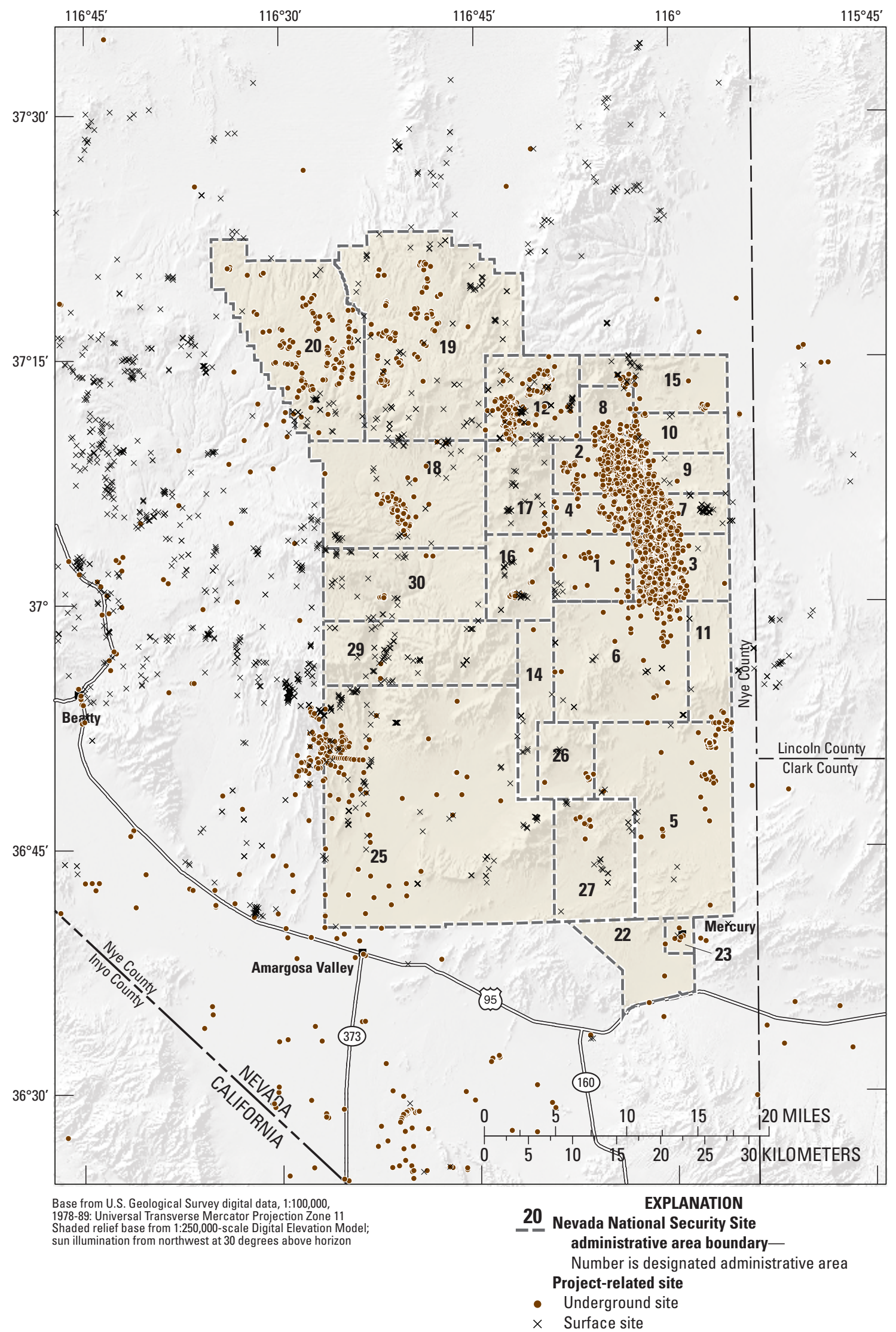

Figure 13. Areal distribution of site-characteristic sites in vicinity of Nevada National Security Site, Nye County, Nevada. 


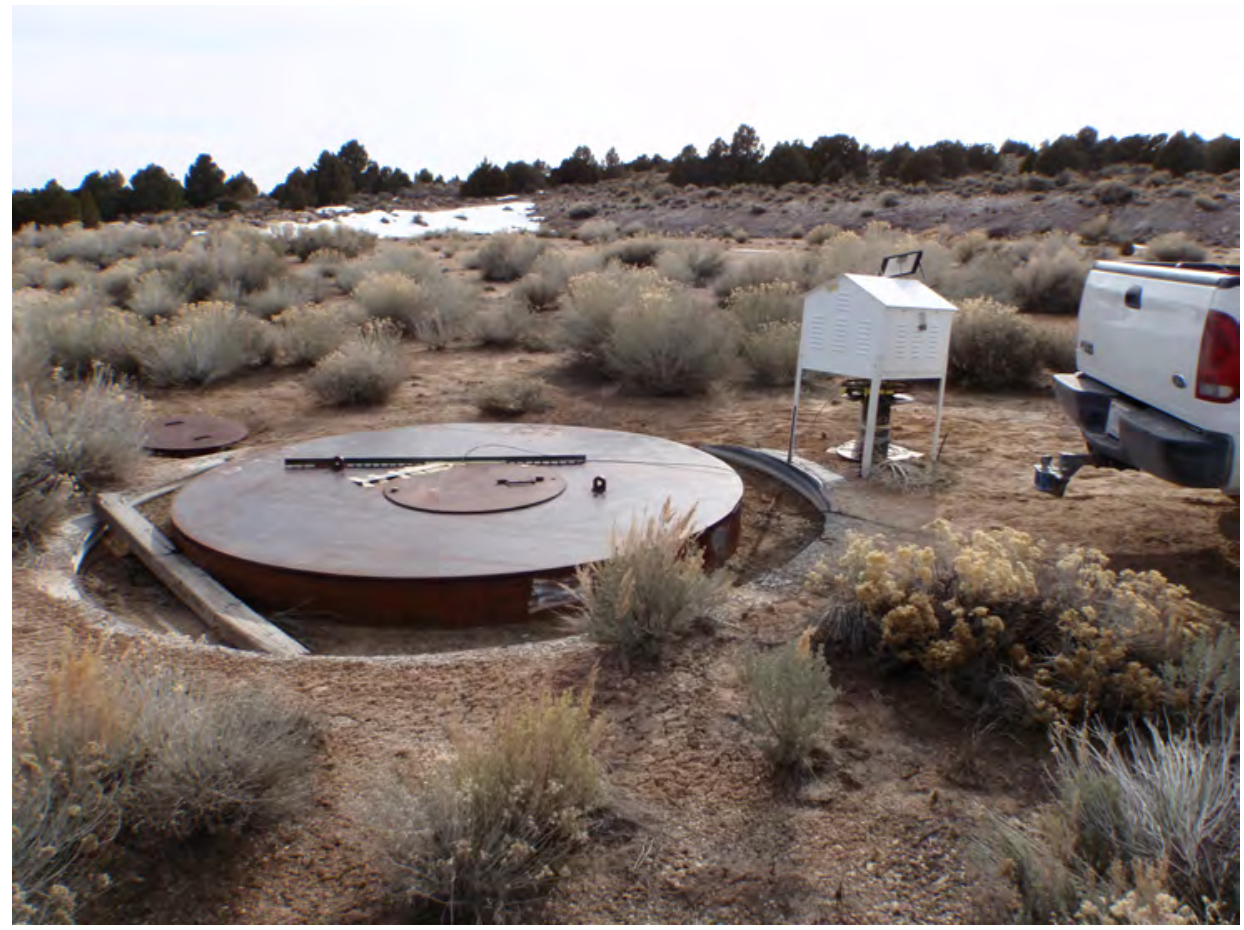

Figure 14. View facing west of U-20bg monitoring hole on Pahute Mesa, Nye County, Nevada. Snow-covered scarp created from construction of drill pad. Corrugated metal pipe surface casing is 136-inch diameter to 8 feet. Conductor casing is 122-inch to 57 feet. 96-inch-diameter open hole to a total depth of 2,200 feet. (Photograph taken by Steven R. Reiner, U.S. Geological Survey.)

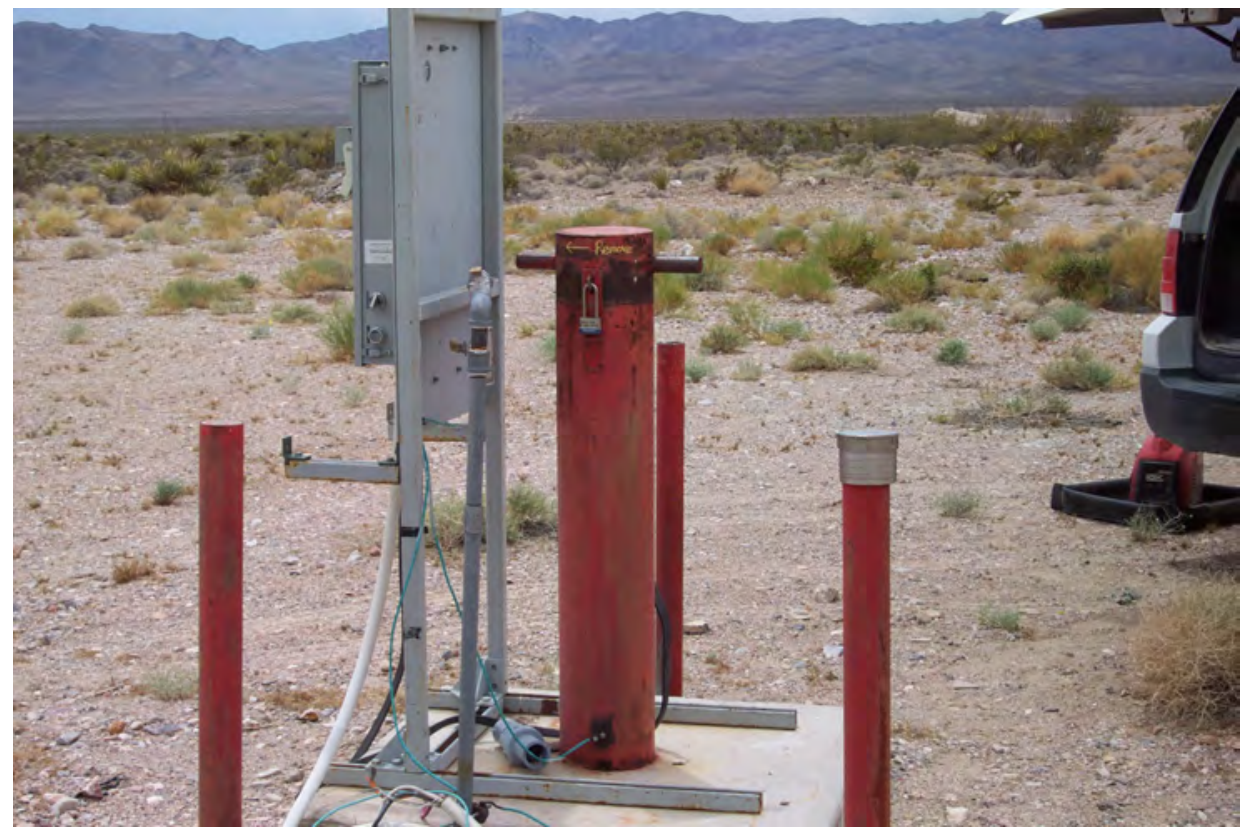

Figure 15. View facing west toward Specter Range of SM-23-1 monitoring hole located in Mercury Valley, Nye Country, Nevada. Protective casing is 6-inch diameter and casing (not shown) is 4-inch diameter to a total depth of 1,332 feet. (Photograph taken by Terry R. Miller, U.S. Geological Survey.) 


\section{Nevada National Security Site Petrographic, Geochemical and Geophysical Database}

The Petrographic, Geochemical and Geophysical (PGG) database of (Warren and others, 2003) provides analyses and descriptions for rocks from both underground and surface sites located on and around the NNSS (igg. 16). Included are detailed quantitative petrographic, chemical, microprobe, and X-ray diffraction analyses, and an extensive suite of geophysical logs. PGG database tables also represent geologic assignments for stratigraphic units, lithology, and alteration (descriptors) for each sample and drill hole. Depth profiles provide selected analyses and descriptors for UE20C (fig. 17), and the equipment used for X-ray fluorescence analysis is shown in (fig. 18).

The PGG database, highly updated since publication by Los Alamos National Laboratory, is presently served by Microsoft ${ }^{\circledR A c c e s s}{ }^{\circledR}$ tables (https://www.sciencebase.gov/ mercury/\#/data/pgg_database). The unique loc_id field in table location provides coordinates and other information for each site. The UnqNoUSGS field from NNSS USGS databases table tbl_nnss_sit_chr has been added to the table location to link PGG database records to NNSS USGS databases records and the redundant SrtOrdUSGS was added to maintain intended sort order. The loc_id field defines the site for each unique sam_id within table sample, which provides descriptors and other information for each sample, and the unique spl_id in table loc_sam_split link identifies analyses by type within the PGG database. Tables included in the original publication remain except where duplicated by other USGS database tables at https://www.sciencebase.gov/mercury/\#/.

\section{Rock-Sample Images}

The USGS photographed rock samples from both underground and surface sites located on and around the NNSS. Images are stored in directories named by USGS hole name. Individual JPG file names include: USGS hole name, sample-box number, and sample interval. Rock-sample images may be identified in the rock-sample database by the USGS hole name, sample interval, and sample box name. Images are available for viewing and download as JPG files (https://www. sciencebase.gov/mercury/index.html\#/images?filter=rock sample).

\section{Thin-Section Images}

The USGS scanned images of thin sections from both underground and surface sites located on and around the NNSS. Images are stored in directories named by USGS hole name. Individual JPG file names include: USGS hole name, thin-section box number, thin-section slot number, sample interval, and polarization (up = unpolarized; p30 = 30 degrees polarization; $\mathrm{p} 60=60$ degrees polarization; $\mathrm{p} 90=$ 90 degrees polarization (extinction - crossed nicols)). Thinsection images may be identified in the rock-sample database by the thin section box_id and slot location. Scanned images of thin sections from the newer Environmental Management Operations Activity (EMOA, formerly Environmental Restoration Project (ER)) holes are provided courtesy of Comprehensive Volcanic Petrographics, LLC (CVP). Images are available for viewing and download as JPG files (https:// www.sciencebase.gov/mercury/index.html\#/images?filter=thin section). 


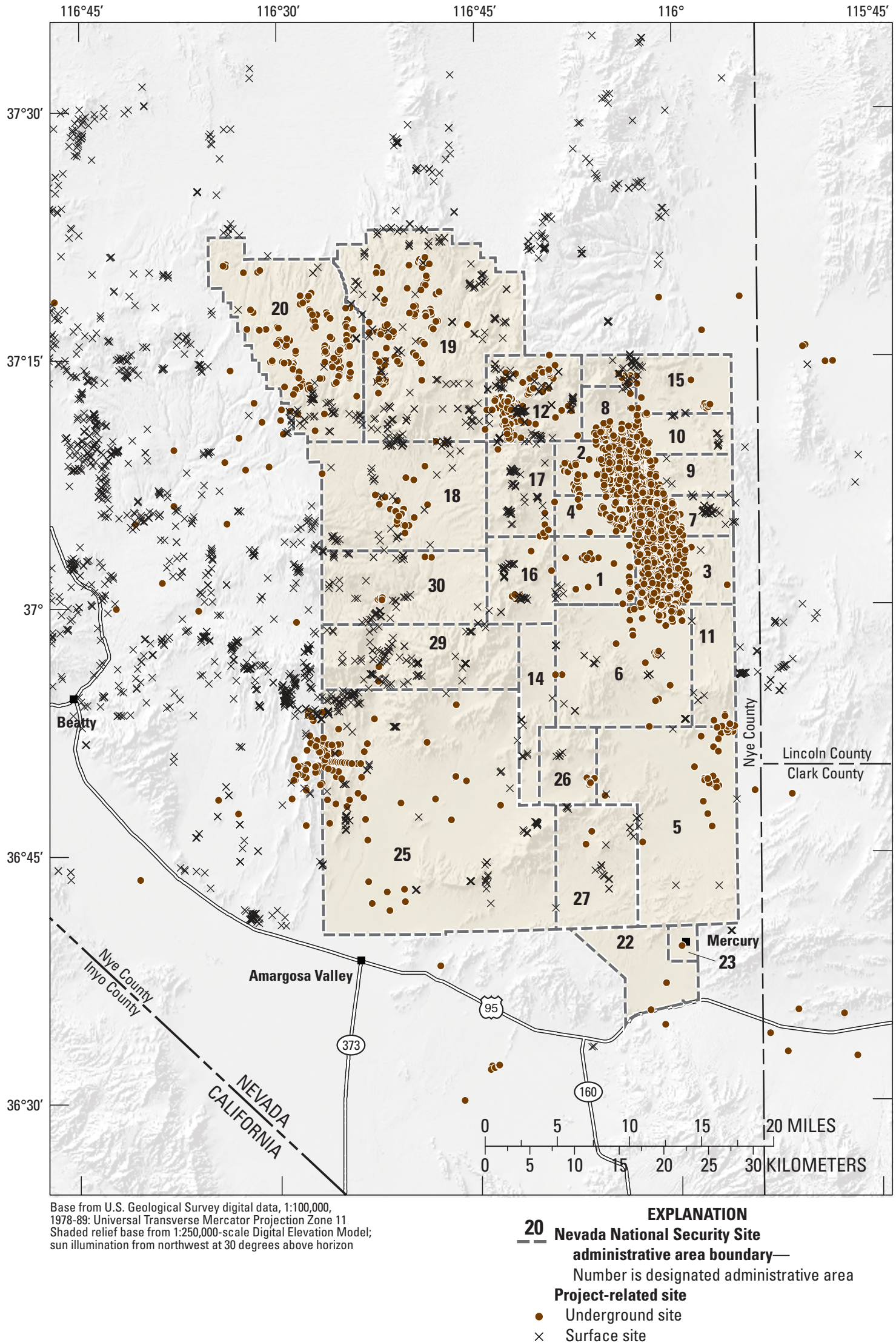

Figure 16. Areal distribution of petrographic, geochemical, and geophysical sites in vicinity of Nevada National Security Site, Nye County, Nevada. 


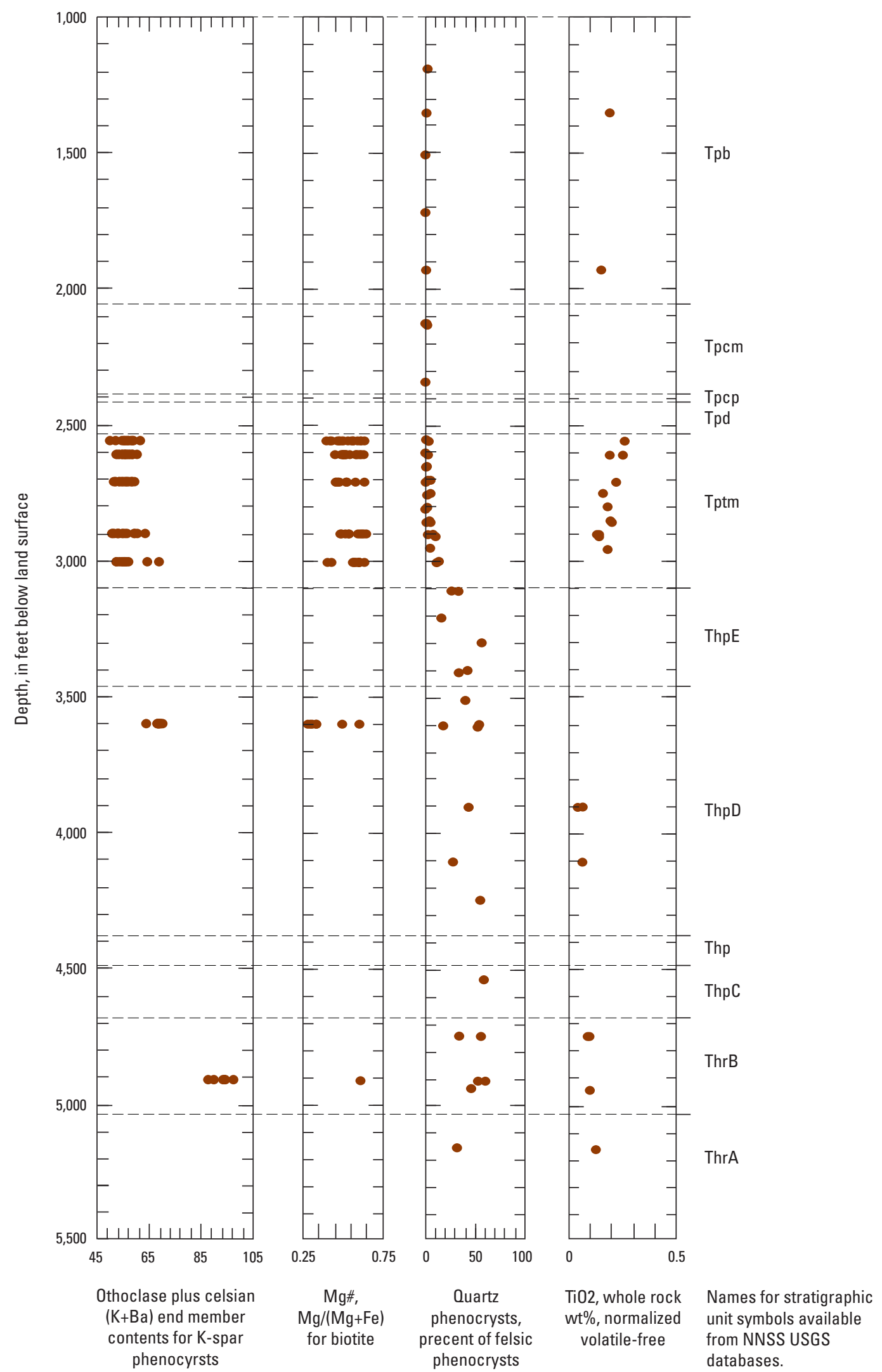

Figure 17. Examples of subsurface geochemical data collected at Nevada National Security Site, Nye County, Nevada. 


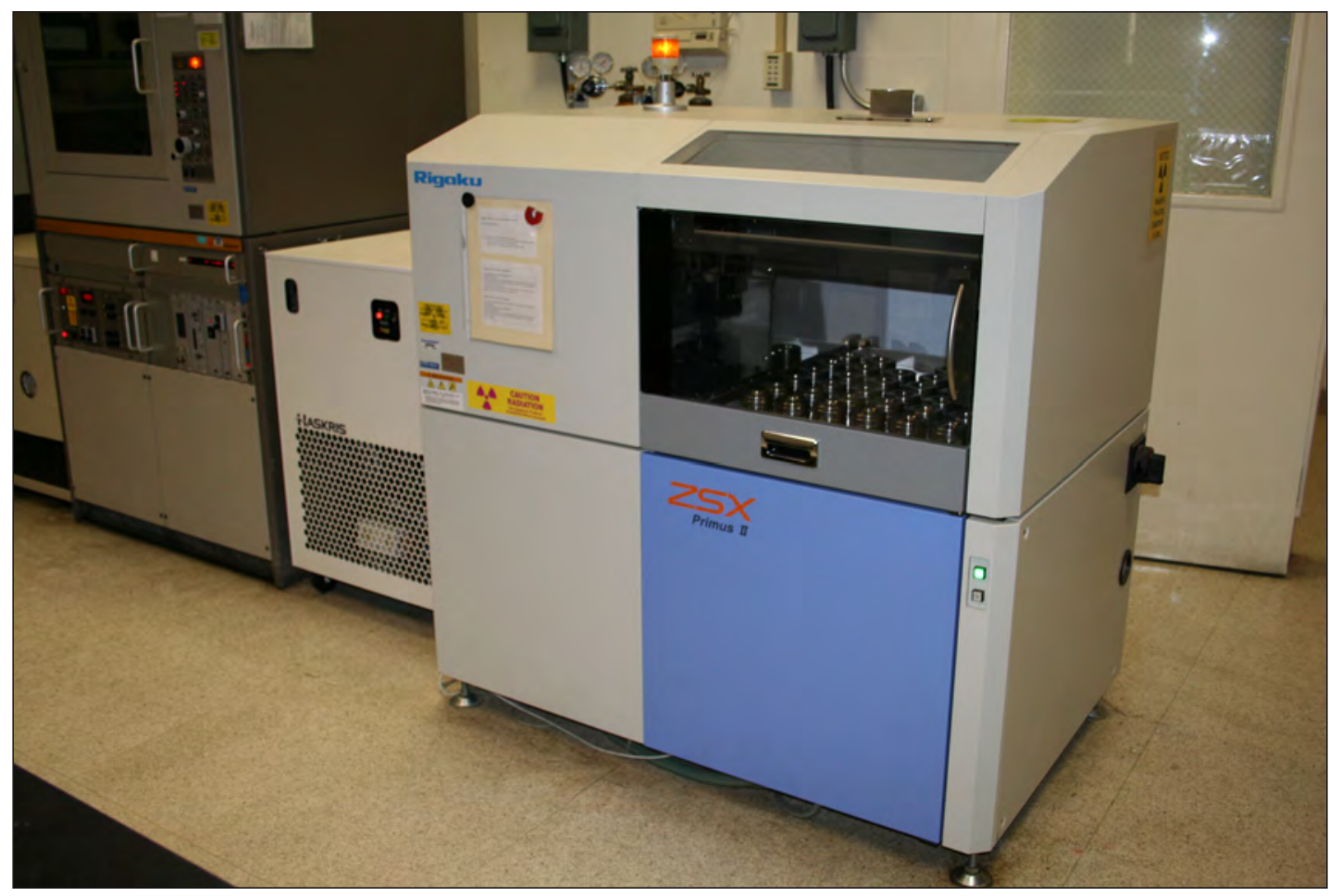

Figure 18. X-ray diffraction and fluorescence equipment. Machine shown on left is X-ray diffraction (XRD) analysis machine. Machine shown on right is X-ray fluorescence (XRF) analysis machine. Photograph taken by Emily C. Kluk, Los Alamos National Laboratory.

\section{Summary}

Between 1951 and 1992, 828 underground tests were conducted on the Nevada National Security Site. Prior to and following these nuclear tests, holes (boreholes, shafts, tunnels, and drifts) were drilled and mined for the collection of rock samples. The U.S. Geological Survey has worked in cooperation with U.S. Department of Energy (and its predecessors) and the National Laboratories since 1956 and the USGS Core Library and Data Center was established at Mercury, Nevada, on the Nevada National Security Site, through a modification to an existing memorandum of understanding dated April 3, 1959. Rock samples collected from these holes are stored in the Core Library and paper copies of records and reports derived from analyses and interpretation of rock samples are stored in the historical files at both the Mercury facility and the USGS office in Henderson, Nevada. The understanding of stratigraphy that underlies the NNSS and vicinity continues to evolve, through interpretation of rock samples from new holes that are drilled and mined, resulting in a multitude of formal and informal units in common use. Rock samples are irreplaceable because pre-test, in-place conditions cannot be recreated and samples cannot be recollected from the many holes destroyed by testing. The condition of the original paper records is rapidly deteriorating, which makes re-compilation unlikely. Documenting these data in a published report will ensure availability for future investigators.

Rock samples have been catalogued by depth interval for samples stored at the U.S. Geological Survey Core Library. Rock-sample data are compiled from paper records contained in file cabinets and from published reports located at the Mercury facility and at the U.S. Geological Survey Henderson office. Rock samples and thin sections are available for both underground and surface sites located at the Nevada National Security Site and vicinity. Lithologic descriptions, physical and mechanical properties, fracture characteristics, and hydraulic-property data from aquifer testing are available for sites located in Frenchman and Yucca Flats and on Buckboard, Pahute, and Rainier Mesas. Lithologic descriptions also are available for holes located in Jackass Flat. These data have been compiled into five digital spreadsheets. 


\section{Acknowledgments}

The author appreciates the cooperation of Bechtel Nevada; Birdwell Division of Seismograph Service Corporation; Desert Research Institute; Fenix and Scisson of Nevada (formerly Fenix and Scisson, Inc.); International Technology Corp.; Los Alamos National Laboratory (formerly Los Alamos Scientific Laboratory); Lawrence Livermore National Laboratory (formerly Lawrence Radiation Laboratory); National Security Technologies, LLC; Nevada Division of Water Resources; Nevada Testing Laboratories; Pittsburg Testing Laboratory; Raytheon Services Nevada; Reynolds Electrical and Engineering Co.; Sandia National Laboratories; Shaw Group, Inc.; Stoller-Navarro Joint Venture; Terra Tek, Inc. (a Schlumberger company, sometimes referred to as TerraTek Research); U.S. Air Force; U.S. Army Corps of Engineers Waterways Experiment Station; U.S. Department of Energy (formerly Energy Research and Development Administration; formerly Atomic Energy Commission); U.S. Department of Defense Defense Threat Reduction Agency (formerly Defense Special Weapons Agency; formerly Defense Nuclear Agency; formerly Defense Atomic Support Agency); USGS Geologic Division; and University of Illinois Talbot Laboratory. The author extends special thanks to Gayle A. Pawloski and Mavrik Zavarin from Lawrence Livermore National Laboratory; Edward M. Kwicklis and Kay Birdsell from Los Alamos National Laboratory; Richard G. Warren from Los Alamos National Laboratory (retired); Sigmond L. Drellack Jr., Lance B. Prothro, and Margaret J. Townsend from National Security Technologies, LLC; Charles E. Russell from Desert Research Institute; Harry R. Covington from USGS (retired); Gary L. Dixon from USGS (retired), and Jerry E. Magner from USGS (retired).

\section{References Cited}

Blankennagel, R.K., and Weir, J.E., Jr., 1973, Geohydrology of the eastern part of Pahute Mesa, Nevada Test Site, Nye County, Nevada: U.S. Geological Survey Professional Paper 712-B, 35 p.

Byers, F.M., Jr., Carr, W.J., and Orkild, P.P., 1989, Volcanic centers of Southwestern Nevada, Evolution of understanding, 1960-1988: Journal of Geophysical Research, v. 94, no. B5, p. 5908-5924.

Byers, F.M., Jr., Carr, W.J., Orkild, P.P., Quinlivan, W.D., and Sargeant, K.A., 1976, Volcanic suites and related cauldrons of Timber Mountain-Oasis Valley caldera complex, Southern Nevada: U.S. Geological Survey Professional Paper 919, 70 p.
Cole, J.C., and Cashman, P.H., 1999, Structural relationships of pre-Tertiary rocks in the Nevada Test Site region, southern Nevada: U.S. Geological Survey Professional Paper 1607, 39 p.

Faunt, C.C., D’Agnese, F.A., and O’Brien, G.M., 2004, D. Hydrology, in Belcher, W.R., ed., Death Valley regional ground-water flow system, Nevada and CaliforniaHydrogeologic framework and transient ground-water flow model: U.S. Geological Survey Scientific Investigations Report 2004-5205, p. 137-163. On-line at: http://water.usgs. gov/pubs/sir/2004/5205/

Fehner, T.R. and Gosling, F.G., 2000, Origins of the Nevada Test Site: U.S. Department of Energy Report DOE/ MA-0518, 95 p.

IT Corporation, 1996a, Underground test area subproject, Phase I, Data analysis task, volume VI-Groundwater flow model data documentation package: Las Vegas, Nev., Report ITLV/10972-181 prepared for the U.S. Department of Energy, 8 volumes, various pagination.

IT Corporation, 1996b, Underground test area subproject, Phase I, Data analysis task, volume I-Geologic model data documentation package: Las Vegas, Nev., Report ITLV/10972-181 prepared for the U.S. Department of Energy, 8 volumes, variously paginated.

Laczniak, R.J., Cole, J.C., Sawyer, D.A., and Trudeau, D.A., 1996, Summary of hydrogeologic controls on ground-water flow at the Nevada Test Site, Nye County, Nevada: U.S. Geological Survey Water-Resources Investigations Report 96-4109, 59 p.

Potter, C.J., Dickerson, R.P., Sweetkind, D.S., Drake II, R.M., Taylor, E.M., Fridrich, C.J., San Juan, C.A., and Day, W.C., 2002, Geologic map of the Yucca Mountain region, Nye County, Nevada: U.S. Geological Survey Geologic Investigations Series Map I-2755, 44 p. text, 2 sheets, scale 1:50,000.

Potter, C.J., Sweetkind, D.S., Dickerson, R.P., and Killgore, M.L., 2001, Hydrostructural map of the Death Valley ground-water basin, Nevada and California: U.S. Geological Survey Miscellaneous Field Studies Map MF-2372, scale 1:350,000, 2 plates with pamphlet. Available online at: http://greenwood.cr.usgs.gov/pub/mf-maps/mf-2372/

Price, C.E., and Thordarson, William, 1961, Ground water test well A, Nevada Test Site, Nye County, Nevada-A summary of lithologic data, aquifer tests, and construction: U.S. Geological Survey Trace Elements Investigations Report 800, 60 p. 
Sawyer, D.A., Fleck, R.J., Lanphere, M.A., Warren, R.G., Broxton, D.E., and Hudson, M.R., 1994, Episodic caldera volcanism in the Miocene southwestern Nevada volcanic field-Revised stratigraphic framework, 40AR/39AR geochronology, and implications from magmatism and extension: Geological Society of America Bulletin, v. 106, p. 1304-1318.

Slate, J.L, Berry, M.E., Rowley, P.D., Fridrich, C.J., Morgan, K.S., Workman, J.B., Young, O.D., Dixon, G.L., Williams, V.S., McKee, E.H., Ponce, D.A., Hildenbrand, T.G., Swadley, W.C., Lundstrom, S.C., Ekren, E.B., Warren, R.G., Cole, J.C., Fleck, R.J., Lanphere, M.A., Sawyer, D.A., Minor, S.A., Grunwald, D.J., Laczniak, R.J., Menges, C.M., Yount, J.C., and Jayko, A.S., 2000, Digital geologic map of the Nevada Test Site and vicinity, Nye, Lincoln, and Clark Counties, Nevada, and Inyo County, California: U.S. Geological Survey Open-File Report 99-554-A, 53 p. text, 2 sheets, scale 1:100,000.

Stewart, J.H., 1980, Geology of Nevada - A discussion to accompany the geologic map of Nevada: Nevada Bureau of Mines and Geology Special Publication 4, 136 p.

Sweetkind, D.S., Belcher, W.R., Faunt, C.C., and Potter, C.J., 2004, B. Geology and Hydrogeology, in Belcher, W.R., ed., Death Valley regional ground-water flow system, Nevada and California-Hydrogeologic framework and transient ground-water flow model: U.S. Geological Survey Scientific Investigations Report 2004-5205, p. 21-98. On-line at: http://water.usgs.gov/pubs/sir/2004/5205/

U.S. Congress, 1989, The containment of underground nuclear explosions: Office of Technology Assessment, Report OTAISC-414, 80 p.
U.S. Department of Energy, 2000, United States Nuclear Tests, July 1945 through September 1992: Nevada Operations Office, Office of External Affairs, Report NVO-209, Revision 15, 162 p.

U.S. Geological Survey, 2005, User's manual for the National Water Information System of the U.S. Geological SurveyGround-Water Site-Inventory System, version 4.4: U.S. Geological Survey Open-File Report 2005-1251, 274 p.

Warren, R.G, Sawyer, D.A., Byers, F.M., Jr., and Cole, G.L., 2003, A petrographic, geochemical, and geophysical database, and stratigraphic framework for the southwestern Nevada volcanic field: Los Alamos National Laboratory Report LA-UR-03-1503, 54 p. Available online at: http:// www.pggdb-swnvf.lanl.gov/

Winograd, I.J., and Thordarson, William, 1975, Hydrogeologic and hydrochemical framework, south-central Great Basin, Nevada-California, with special reference to the Nevada Test Site: U.S. Geological Survey Professional Paper 712-C, $126 \mathrm{p}$.

Workman, J.B., Menges, C.M., Page, W.R., Taylor, E.M., Ekren, E.B., Rowley, P.D., Dixon, G.L., Thompson, R.A., and Wright, L.A., 2002, Geologic map of the Death Valley ground-water model area, Nevada and California: U.S. Geological Survey Miscellaneous Field Studies Map MF-2381-A, 26 p., 2 sheets, scale 1:250,000. 

For more information contact:

Director, Nevada Water Science Center

U.S. Geological Survey

2730 N. Deer Run Road

Carson City, Nevada 89701

http://nevada.usgs.gov 


\section{营}

